\title{
Species of Dendrostoma (Erythrogloeaceae, Diaporthales) associated with chestnut and oak canker diseases in China
}

\author{
Ning Jiang', Xin-Lei Fan', Pedro W. Crous², Cheng-Ming Tian' \\ I The Key Laboratory for Silviculture and Conservation of the Ministry of Education, Beijing Forestry Uni- \\ versity, Beijing 100083, China 2 Westerdijk Fungal Biodiversity Institute, Uppsalalaan 8, 3584 CT, Utrecht, \\ The Netherlands
}

Corresponding author: Cheng-Ming Tian (chengmt@bjfu.edu.cn)

Academic editor: C. Gueidan | Received 17 November 2018 | Accepted 17 December 2018 | Published 6 March 2019

Citation: Jiang N, Fan X-L, Crous PW, Tian C-M (2019) Species of Dendrostoma (Erythrogloeaceae, Diaporthales) associated with chestnut and oak canker diseases in China. MycoKeys 48: 67-96. https://doi.org/10.3897/ mycokeys. 48.31715

\begin{abstract}
Dendrostoma was recently proposed in Erythrogloeaceae (Diaporthales, Sordariomycetes), with all known members recorded as being plant pathogenic on economically important tree hosts. During our collections of Dendrostoma species in China, mild to severe canker symptoms were observed on sweet chestnut (Castanea mollissima) and oak (Quercus spp.) trees. Dead and dying plant tissues exhibiting Dendrostoma canker symptoms were sampled for fungal isolation. A total of 37 Dendrostoma isolates were obtained and analysed using morphological characteristics and molecular data (ITS, LSU, RPB2, TEF1-a). Based on these data, 10 novel clades could be distinguished, which also proved to represent morphologically distinct species described here as Dendrostoma aurorae, $D$. castaneae, D. castaneicola, D. chinense, $D$. dispersum, D. parasiticum, D. qinlingense, $D$. quercus, $D$. shaanxiense and $D$. shandongense spp. nov. A key to species of the genus is also provided.
\end{abstract}

\section{Keywords}

Canker, Castanea, multi-gene phylogeny, Quercus, systematics

\section{Introduction}

The family Erythrogloeaceae was established to accommodate Chrysocrypta, Disculoides, and Erythrogloeum, which exhibit epiphyllous acervuli along with subcylindrical to ampulliform conidiogenous cells and aseptate conidia (Senanayake et al. 2017). 
Erythrogloeum (Petrak 1953) is the type genus of Erythrogloeaceae and causes severe anthracnose on Hymenaea courbaril in South America (Ferreira et al. 1992). Chrysocrypta was first proposed in Cryphonectriaceae, being associated with leaf spots on Corymbia spp. in Australia (Crous et al. 2012a), but was subsequently transferred to Erythrogloeaceae, based on DNA sequence data (Senanayake et al. 2017). Disculoides was introduced with two initial species, D. eucalypti and D. eucalyptorum, discovered on diseased Eucalyptus leaves in Australia (Crous et al. 2012b). Two additional Disculoides species, $D$. calophyllae and $D$. corymbiae, were subsequently reported as foliar pathogens of Corymbia calophylla (Crous et al. 2016, 2017).

Dendrostoma (Erythrogloeaceae, Diaporthales) was recently introduced as a phytopathogenic fungal genus causing canker diseases on several economic hardwoods such as Malus spectabilis, Osmanthus fragrans and Quercus acutissima (Fan et al. 2018). Subsequently, Dendrostoma leiphaemia on Quercus trees was transferred from Amphiporthe based on ITS and LSU sequences analysis (Senanayake et al. 2018). Dendrostoma represents one of four genera in the family, but is the only one known to have a sexual morph. Hence, Erythrogloeaceae can be distinguished from the other diaporthalean families by multiguttulate and bicellular ascospores that are constricted at the septum and acervular conidiomata, with subcylindrical to ampulliform conidiogenous cells and hyaline to olivaceous, aseptate conidia (Rossman et al. 2007, Voglmayr and Jaklitsch 2014, Senanayake et al. 2017, Voglmayr et al. 2017, Fan et al. 2018).

The Erythrogloeaceae, including Chrysocrypta, Dendrostoma, Disculoides and Erythrogloeum, represent a family of fungal pathogens occurring on several commercially important tree genera such as Corymbia, Eucalyptus, Hymenaea, Malus, Osmanthus and Quercus in Australia, Brazil, China and Costa Rica (Petrak 1953, Ferreira et al. 1992, Crous et al. 2012a, b, 2016, 2017, Fan et al. 2018). Considering the importance of these tree diseases and the lack of taxonomic information on Dendrostoma, we conducted several surveys for members of the genus in China.

The aims of present study were (i) to describe the important Dendrostoma spp. associated with canker diseases on chestnut and oak trees in China and (ii) to provide a multi-gene phylogeny for the genus Dendrostoma based on a large set of freshly collected specimens in China. In agreement with previous taxonomic studies in Erythrogloeaceae, where different Disculoides spp. were discovered on Myrtaceae (Crous et al. 2012a, b, 2016, 2017), several Dendrostoma spp. were found on Fagaceae (Castanea and Quercus), being associated with mild to severe canker diseases. The Dendrostoma species were subsequently classified based on morphological characteristics and phylogenetic data.

\section{Materials and methods}

\section{Sample collections and fungal isolates}

Surveys for Dendrostoma species were conducted in plantations, nurseries, parks, gardens, on mountains and natural reserves in Beijing, Hebei, Shaanxi, Shandong, Tian- 
jin and Zhejiang Provinces in China from 2017 to 2018. Typical canker symptoms were observed on stems, branches and twigs of different hosts, including Castanea mollissima, Quercus aliena, Q. aliena var. acuteserrata, Q. wutaishanica and other Quercus species (Fig. 1). Diseased samples were collected and placed in paper bags, then transferred to the laboratory for further study.

A total of 37 Dendrostoma isolates were established by removing a mucoid spore mass from sporulating ascomata and conidiomata produced on diseased bark, spreading the suspension on the surface of potato dextrose agar (PDA) plates and incubating
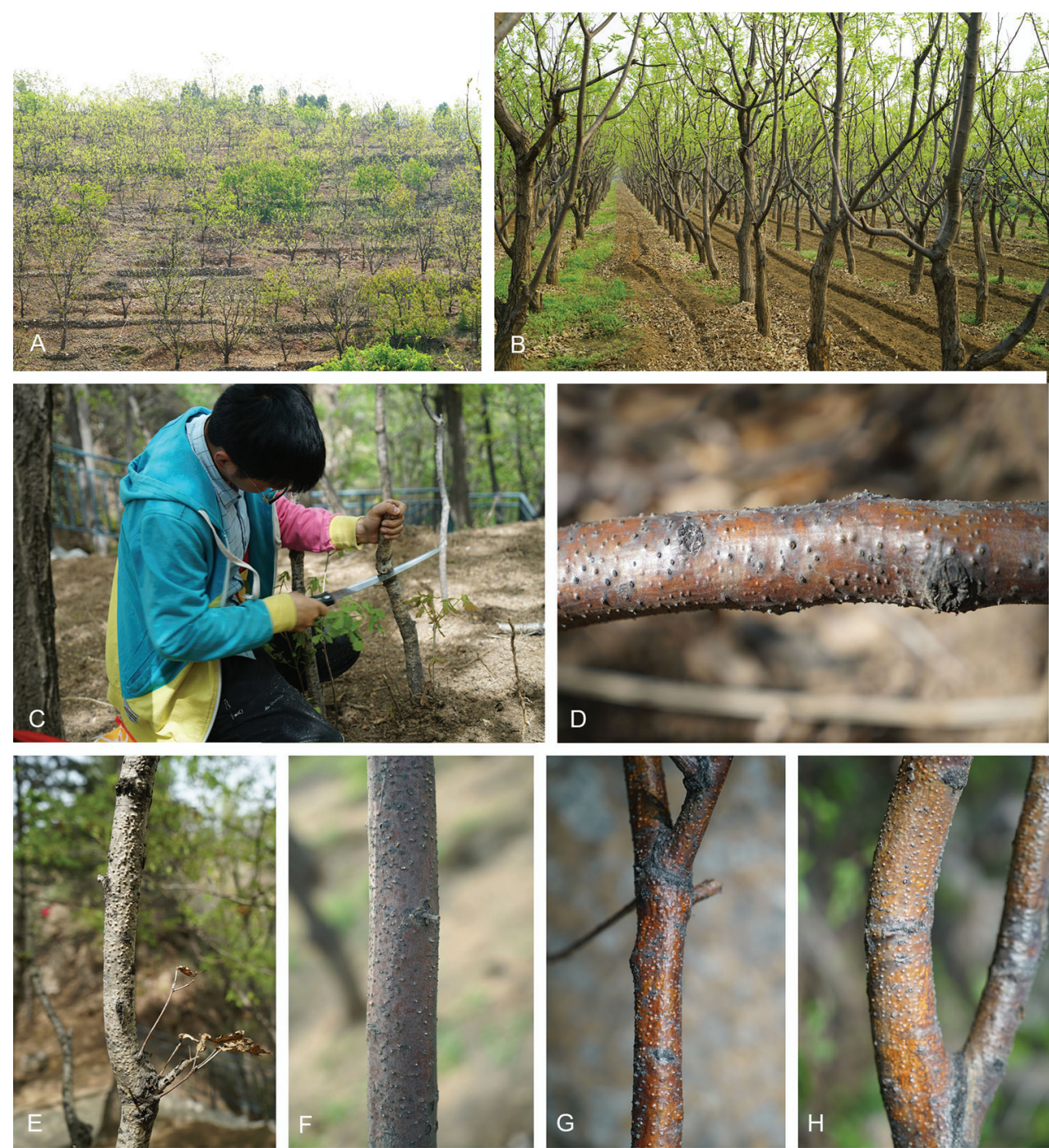

Figure I. Chestnut plantations and Dendrostoma canker symptoms. A A chestnut plantation on the mountain B A chestnut plantation on the plain C Collection of the dead trees killed by Dendrostoma pathogens D-H Dendrostoma canker symptoms on host branches. 
the plates at $25^{\circ} \mathrm{C}$ in the dark for up to $24 \mathrm{~h}$. Single germinating spores were then transferred to clean plates under a dissecting microscope with a sterile needle. Specimens and isolates were deposited in the Museum of Beijing Forestry University (BJFC). Axenic cultures are maintained in the China Forestry Culture Collection Centre (CFCC).

\section{Morphological analysis}

The identification of Dendrostoma spp. was based on morphological features observed on the natural substrates. Cross-sections for ascomata and conidiomata from tree barks were prepared by hand using a double-edged blade under a dissecting microscope. At least 10 conidiomata/ascomata, 10 asci and 50 conidia/ascospores were measured to calculate the mean size and standard deviation. Measurements are reported as maxima and minima in parentheses and the range representing the mean plus and minus the standard deviation of the number of measurements is given in parentheses (Voglmayr et al. 2017). Microscopy photographs were captured with a Nikon Eclipse 80i compound microscope equipped with a Nikon digital sight DS-Ri2 high definition colour camera, using differential interference contrast illumination. Nomenclatural novelties and descriptions were deposited in MycoBank (Crous et al. 2004). Cultural characteristics were recorded for isolates incubated on PDA in the dark at $25^{\circ} \mathrm{C}$.

\section{DNA extraction, PCR amplification and sequencing}

Genomic DNA was extracted from fungal colonies growing on PDA using a modified cetyl trimethyl ammonium bromide method (CTAB; Doyle and Doyle 1990, Zhang et al. 2010). The ITS region was amplified using the primers ITS1 and ITS4 (White et al. 1990), the LSU region with the primers LR0R and LR5 (Vilgalys and Hester 1990), the RPB2 region with primers $\mathrm{fRPB} 2-5 \mathrm{~F}$ and $\mathrm{fRPB} 2-7 \mathrm{cR}$ (Liu et al. 1999) and the partial TEF1-a gene with the primers EF1-728F and EF1-986R (Carbone and Kohn 1999). The PCR mixture for all regions consisted of $1 \mu$ genomic DNA, 3 $\mathrm{mM} \mathrm{MgCl}, 20 \mu \mathrm{M}$ of each dNTP, $0.2 \mu \mathrm{M}$ of each primer and $0.25 \mathrm{U}$ rTAQ DNA polymerase (TaKaRa, Shiga). Amplification of LSU and ITS were accomplished by an initial step of 2 min at $95^{\circ} \mathrm{C}$, followed by 35 cycles of $30 \mathrm{~s}$ at $95^{\circ} \mathrm{C}, 30 \mathrm{~s}$ at $51^{\circ} \mathrm{C}$ and $40 \mathrm{~s}$ at $72{ }^{\circ} \mathrm{C}$, with a final extension of $10 \mathrm{~min}$ at $72{ }^{\circ} \mathrm{C}$. For TEF1- $a$ amplification, the 35 cycles consisted of initiation at $95^{\circ} \mathrm{C}$ for $8 \mathrm{~min}$, denaturation at $95^{\circ} \mathrm{C}$ for $15 \mathrm{~s}$, annealing at $55^{\circ} \mathrm{C}$ for $20 \mathrm{~s}$, elongation at $72{ }^{\circ} \mathrm{C}$ for $1 \mathrm{~min}$ and a final extension of 5 min at $72{ }^{\circ} \mathrm{C}$. For $R P B 2$, amplification of 35 cycles consisted of initiation at $95^{\circ} \mathrm{C}$ for $5 \mathrm{~min}$, denaturation at $95^{\circ} \mathrm{C}$ for $30 \mathrm{~s}$, annealing at $52^{\circ} \mathrm{C}$ for $1 \mathrm{~min}$, elongation at $72{ }^{\circ} \mathrm{C}$ for $1 \mathrm{~min}$ and a final extension of $10 \mathrm{~min}$ at $72{ }^{\circ} \mathrm{C}$. The DNA sequencing was performed using an ABI PRISM 3730XL DNA Analyzer with BigDye Terminater Kit v. 3.1 (Invitrogen, Carlsbad) at the Shanghai Invitrogen Biological Technology Company Limited (Beijing). 


\section{Phylogenetic analyses}

Sequences generated from the above primers of the different genomic regions (ITS, LSU, TEF1- $a$ and RPB2) were analysed in comparison with those of Dendrostoma mali (CFCC 52102), D. leiphaemia (CBS 187.37), D. osmanthi (CFCC 52106, CFCC 52107, CFCC 52108 and CFCC 52109) and D. quercinum (CFCC 52103, CFCC 52104 and CFCC 52105) from Fan et al. (2018) and Senanayake et al. (2018). Corymbia corymbiae (CBS 132528), Disculoides eucalypti (CBS 132183) and D. eucalyptorum (CBS 132184) were selected as the outgroup taxa (Crous et al. 2012a, b). All sequences were aligned using MAFFT v. 6 (Katoh and Toh 2010) and edited manually using MEGA v. 6 (Tamura et al. 2013). Phylogenetic analyses were performed using PAUP v. $4.0 \mathrm{~b} 10$ for maximum parsimony (MP) analysis (Swofford 2003) and PhyML v. 3.0 for Maximum Likelihood (ML) analysis (Guindon et al. 2010). The first analyses were performed on the combined multi-gene dataset (ITS, LSU, TEF1- $a$ and RPB2) to compare isolates of Erythrogloeaceae species to ex-type sequence data from recent studies (Table 1 ).

A partition homogeneity test with heuristic search and 1000 replicates was performed using PAUP v. 4.0b10 to assess the discrepancy amongst the ITS, LSU, TEF1-a and $R P B 2$ sequence datasets in reconstructing phylogenetic trees. MP analysis was run using a heuristic search option of 1000 search replicates with random-additions of sequences with a tree bisection and reconnection algorithm. Maxtrees were set to 5000, branches of zero length were collapsed and all equally parsimonious trees were saved. Other calculated parsimony scores were tree length (TL), consistency index $(\mathrm{CI})$, retention index (RI) and rescaled consistency (RC). ML analysis was performed using a GTR site substitution model including a gamma-distributed rate heterogeneity and a proportion of invariant sites (Guindon et al. 2010). The branch support was evaluated using a bootstrapping method of 1000 replicates (Hillis and Bull 1993). Phylograms were shown using FigTree v. 1.3.1 (Rambaut and Drummond 2010). Novel sequences generated in the current study were deposited in GenBank (Table 1) and the aligned matrices used for phylogenetic analyses in TreeBASE (accession number: S22929).

\section{Results}

\section{Phylogenetic analyses}

The alignment based on the combined sequence dataset (ITS, LSU, TEF1- $a$ and $R P B 2$ ) included 46 ingroup taxa and three outgroup taxa, comprising 3536 characters in the aligned matrix. Of these, 2612 characters were constant, 175 variable characters were parsimony-uninformative and 749 characters were parsimony informative (101 from ITS, 21 from LSU, 389 from TEF1- $a$ and 238 from RPB2). The MP analysis resulted in 108 equally most parsimonious trees $(\mathrm{TL}=1590, \mathrm{CI}=0.744, \mathrm{RI}=0.897$, $\mathrm{RC}=0.668$ ); the first tree is shown in Fig. 2. The phylogram based on the four gene sequences indicated 10 new species in Dendrostoma (Fig. 2), as described below. 
Table I. Isolates and GenBank accession numbers used in the phylogenetic analyses.

\begin{tabular}{|c|c|c|c|c|c|c|c|c|}
\hline \multirow[t]{2}{*}{ Species } & \multirow[t]{2}{*}{ Culture } & \multirow[t]{2}{*}{ Location } & \multirow[t]{2}{*}{ Host } & \multirow{2}{*}{$\begin{array}{l}\text { Host } \\
\text { family }\end{array}$} & \multicolumn{4}{|c|}{ GenBank accession numbers } \\
\hline & & & & & ITS & LSU & $T E F 1-a$ & $R P B 2$ \\
\hline Chrysocrypta corymbiae & CBS $132528^{*}$ & Australia & Corymbia sp. & Myrtaceae & JX069867 & JX069851 & MH545457 & MH545415 \\
\hline \multirow[t]{2}{*}{ Dendrostoma aurorae } & CFCC $52753^{*}$ & China & Castanea mollissima & Fagaceae & MH542498 & MH542646 & MH545447 & MH545405 \\
\hline & CFCC 52754 & China & Castanea mollissima & Fagaceae & MH542499 & MH542647 & MH545448 & MH545406 \\
\hline \multirow[t]{8}{*}{ Dendrostoma castaneae } & CFCC $52745^{*}$ & China & Castanea mollissima & Fagaceae & MH542488 & MH542644 & MH545437 & MH545395 \\
\hline & CFCC 52746 & China & Castanea mollissima & Fagaceae & MH542489 & NA & MH545438 & MH545396 \\
\hline & CFCC 52747 & China & Castanea mollissima & Fagaceae & MH542490 & NA & MH545439 & MH545397 \\
\hline & CFCC 52748 & China & Castanea mollissima & Fagaceae & MH542491 & NA & MH545440 & MH545398 \\
\hline & CFCC 52749 & China & Castanea mollissima & Fagaceae & MH542492 & MH542645 & MH545441 & MH545399 \\
\hline & CFCC 52750 & China & Castanea mollissima & Fagaceae & MH542493 & NA & MH545442 & MH545400 \\
\hline & CFCC 52751 & China & Castanea mollissima & Fagaceae & MH542494 & NA & MH545443 & MH545401 \\
\hline & CFCC 52752 & China & Castanea mollissima & Fagaceae & MH542495 & NA & MH545444 & MH545402 \\
\hline \multirow[t]{2}{*}{ Dendrostoma castaneicola } & CFCC $52743^{*}$ & China & Castanea mollissima & Fagaceae & MH542496 & NA & MH545445 & MH545403 \\
\hline & CFCC 52744 & China & Castanea mollissima & Fagaceae & MH542497 & NA & MH545446 & MH545404 \\
\hline \multirow[t]{4}{*}{ Dendrostoma chinense } & CFCC $52755^{*}$ & China & Castanea mollissima & Fagaceae & MH542500 & MH542648 & MH545449 & MH545407 \\
\hline & CFCC 52756 & China & Castanea mollissima & Fagaceae & MH542501 & MH542649 & MH545450 & MH545408 \\
\hline & CFCC 52757 & China & Castanea mollissima & Fagaceae & MH542502 & MH542650 & MH545451 & MH545409 \\
\hline & CFCC 52758 & China & Castanea mollissima & Fagaceae & MH542503 & MH542651 & MH545452 & MH545410 \\
\hline \multirow[t]{2}{*}{ Dendrostoma dispersum } & CFCC 52730* & China & Quercus sp. & Fagaceae & MH542467 & MH542629 & MH545416 & MH545374 \\
\hline & CFCC 52731 & China & Quercus sp. & Fagaceae & MH542468 & MH542630 & MH545417 & MH545375 \\
\hline Dendrostoma leiphaemia & CBS 187.37 & NA & Quercus sp. & Fagaceae & MH855882 & MH867393 & NA & NA \\
\hline Dendrostoma mali & CFCC $52102^{*}$ & China & Malus spectabilis & Rosaceae & MG682072 & MG682012 & MG682032 & MG682052 \\
\hline \multirow[t]{4}{*}{ Dendrostoma osmanthi } & CFCC 52106* & China & Osmanthus fragrans & Oleaceae & MG682073 & MG682013 & MG682033 & MG682053 \\
\hline & CFCC 52108 & China & Osmanthus fragrans & Oleaceae & MG682074 & MG682014 & MG682034 & MG682054 \\
\hline & CFCC 52107 & China & Osmanthus fragrans & Oleaceae & MG682075 & MG682015 & MG682035 & MG682055 \\
\hline & CFCC 52109 & China & Osmanthus fragrans & Oleaceae & MG682076 & MG682016 & MG682036 & MG682056 \\
\hline \multirow[t]{6}{*}{ Dendrostoma parasiticum } & CFCC 52761 & China & Castanea mollissima & Fagaceae & MH542480 & MH542636 & MH545429 & MH545387 \\
\hline & CFCC 52763 & China & Castanea mollissima & Fagaceae & MH542481 & MH542637 & MH545430 & MH545388 \\
\hline & CFCC $52762^{*}$ & China & $\begin{array}{c}\text { Quercus } \\
\text { wutaishanica }\end{array}$ & Fagaceae & MH542482 & MH542638 & MH545431 & MH545389 \\
\hline & CFCC 52764 & China & Quercus aliena & Fagaceae & MH542483 & MH542639 & MH545432 & MH545390 \\
\hline & CFCC 52765 & China & Castanea mollissima & Fagaceae & MH542484 & MH542640 & MH545433 & MH545391 \\
\hline & CFCC 52766 & China & $\begin{array}{l}\text { Quercus aliena var. } \\
\text { acuteserrata }\end{array}$ & Fagaceae & MH542485 & MH542641 & MH545434 & MH545392 \\
\hline \multirow[t]{2}{*}{ Dendrostoma qinlingense } & CFCC $52732^{*}$ & China & $\begin{array}{c}\text { Quercus } \\
\text { wutaishanica }\end{array}$ & Fagaceae & MH542471 & MH542633 & MH545420 & MH545378 \\
\hline & CFCC 52733 & China & $\begin{array}{l}\text { Quercus aliena var. } \\
\text { acuteserrata }\end{array}$ & Fagaceae & MH542472 & MH542634 & MH545421 & MH545379 \\
\hline \multirow[t]{3}{*}{ Dendrostoma quercinum } & CFCC $52103^{*}$ & China & Quercus acutissima & Fagaceae & MG682077 & MG682017 & MG682037 & MG682057 \\
\hline & CFCC 52104 & China & Quercus acutissima & Fagaceae & MG682078 & MG682018 & MG682038 & MG682058 \\
\hline & CFCC 52105 & China & Quercus acutissima & Fagaceae & MG682079 & MG682019 & MG682039 & MG682059 \\
\hline \multirow[t]{7}{*}{ Dendrostoma quercus } & CFCC 52734 & China & Quercus sp. & Fagaceae & MH542473 & $\mathrm{NA}$ & MH545422 & MH545380 \\
\hline & CFCC 52735 & China & Quercus sp. & Fagaceae & MH542474 & NA & MH545423 & MH545381 \\
\hline & CFCC 52737 & China & Quercus sp. & Fagaceae & MH542475 & NA & MH545424 & MH545382 \\
\hline & CFCC 52739* & China & Quercussp. & Fagaceae & MH542476 & MH542635 & MH545425 & MH545383 \\
\hline & CFCC 52738 & China & Quercus sp. & Fagaceae & MH542477 & NA & MH545426 & MH545384 \\
\hline & CFCC 52736 & China & Quercus sp. & Fagaceae & MH542478 & NA & MH545427 & MH545385 \\
\hline & CFCC 52740 & China & Quercus sp. & Fagaceae & MH542479 & NA & MH545428 & MH545386 \\
\hline \multirow[t]{2}{*}{ Dendrostoma shaanxiense } & CFCC $52741^{*}$ & China & Castanea mollissima & Fagaceae & MH542486 & MH542642 & MH545435 & MH545393 \\
\hline & CFCC 52742 & China & Castanea mollissima & Fagaceae & MH542487 & MH542643 & MH545436 & MH545394 \\
\hline \multirow[t]{2}{*}{ Dendrostoma shandongense } & CFCC $52759^{*}$ & China & Castanea mollissima & Fagaceae & MH542504 & MH542652 & MH545453 & MH545411 \\
\hline & CFCC 52760 & China & Castanea mollissima & Fagaceae & MH542505 & MH542653 & MH545454 & MH545412 \\
\hline Disculoides encalypti & CBS $132183^{*}$ & Australia & Eucalyptus sp. & Myrtaceae & JQ685517 & JQ685523 & MH545455 & MH545413 \\
\hline Disculoides encalyptorum & CBS $132184^{*}$ & Australia & $\begin{array}{l}\text { Eucalyptus } \\
\text { viminalis }\end{array}$ & Myrtaceae & JQ685518 & JQ685524 & MH545456 & MH545414 \\
\hline
\end{tabular}




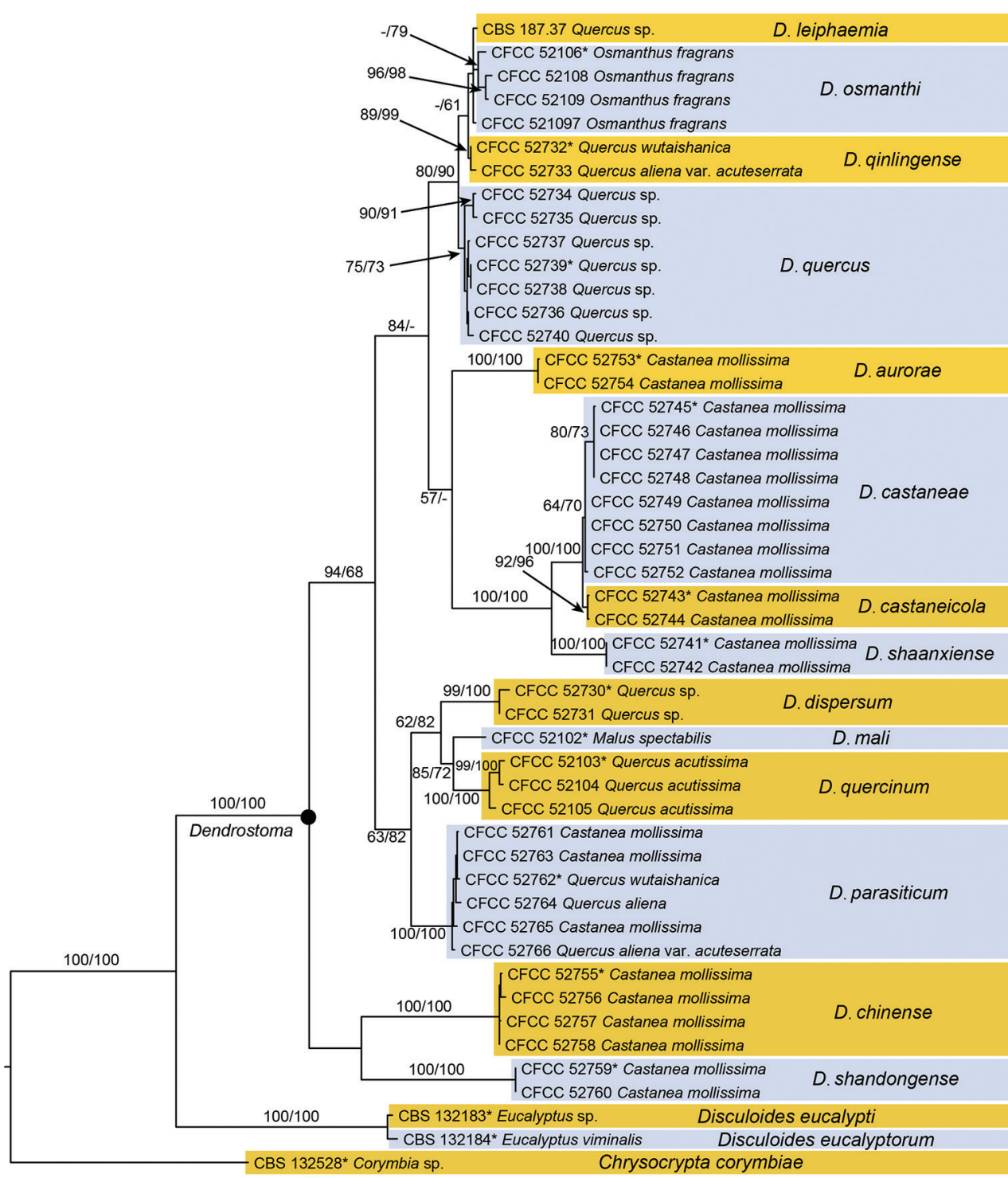

Figure 2. Phylogenetic tree based on an MP analysis of a combined DNA dataset of ITS, LSU, TEF1-a and RPB2 gene sequences for the species of Dendrostoma. Bootstrap values $\geq 50 \%$ for MP and ML analyses are presented at the branches. Isolates representing ex-type material are marked with *. 


\section{Taxonomy}

\section{Dendrostoma X.L. Fan \& C.M. Tian, Persoonia 40: 126 (2018)}

Type species. Dendrostoma mali X.L. Fan \& C.M. Tian.

Description. Sexual morph: Pseudostromata small to large, distinct, circular, erumpent, consisting of an inconspicuous ectostromatic disc, semi-immersed to superficial, causing a pustulate bark surface. Ectostromatic disc flat or concave, orange, surrounded by bark flaps. Central column beneath the disc more or less conical. Stromatic zones lacking. Ascomata perithecial, conspicuous, umber to fuscous black, embedded in orange to umber pseudostromatic tissue, regularly scattered, surrounding the ectostromatic disc, with small to long ostioles that emerge within the ectostromatic disc. Ostioles flat in the disc or sometimes slightly projecting, cylindrical, sometimes obscuring the disc, covered by an orange, umber to fuscous black crust. Paraphyses deliquescent. Asci fusoid, 8-spored, 2-3-seriate, with an apical ring, becoming detached from the perithecial wall. Ascospores hyaline, fusoid to cylindrical, symmetrical to asymmetrical, straight to curved, bicellular, with a median septum, constricted at the septum, smooth, multiguttulate. Asexual morph: Conidiomata pycnidial, spherical to conical to pulvinate, occurring separately, immersed to semi-immersed in bark; wall of several layers of yellow textura angularis. Central column beneath the disc conical or not. Conidiophores reduced to conidiogenous cells. Conidiogenous cells lining the inner walls of cavity, hyaline, smooth, subcylindrical to ampulliform. Conidia hyaline, aseptate, smooth, multiguttulate or not, thin-walled, ellipsoid to fusoid, straight to curved.

\section{Dendrostoma aurorae C.M. Tian \& N. Jiang, sp. nov.} MycoBank: MB826795

Figure 3

Diagnosis. Dendrostoma aurorae differs from $D$. chinensis and $D$. shandongense by the existence of obvious central column.

Holotype. CHINA. Shaanxi Province: Lan'gao County, chestnut plantation, $32^{\circ} 13^{\prime} 43^{\prime \prime N}, 109^{\circ} 00^{\prime} 44^{\prime \prime E}, 1820 \mathrm{~m}$ a.s.l., on branches of Castanea mollissima, 3 Jul. 2017, N. Jiang (holotype: BJFC-S1561; ex-type culture: CFCC 52753).

Etymology. Aurorae, referring to the orange conidiomata with exuding conidial tendrils.

Description. Sexual morph not observed. Asexual morph: Conidiomata pycnidial, conical to pulvinate, occurring separately, bright yellow to orange, semi-immersed in bark, 300-500 $\mu \mathrm{m}$ high, 800-1400 $\mu \mathrm{m}$ diam.; wall of several layers of bright yellow textura angularis; conidiomata exuding slimy orange masses of conidia; central column beneath the disc more or less conical, pale yellow. Conidiophores reduced to conidiogenous cells. Conidiogenous cells lining the inner walls of the cavity, hyaline, smooth, 

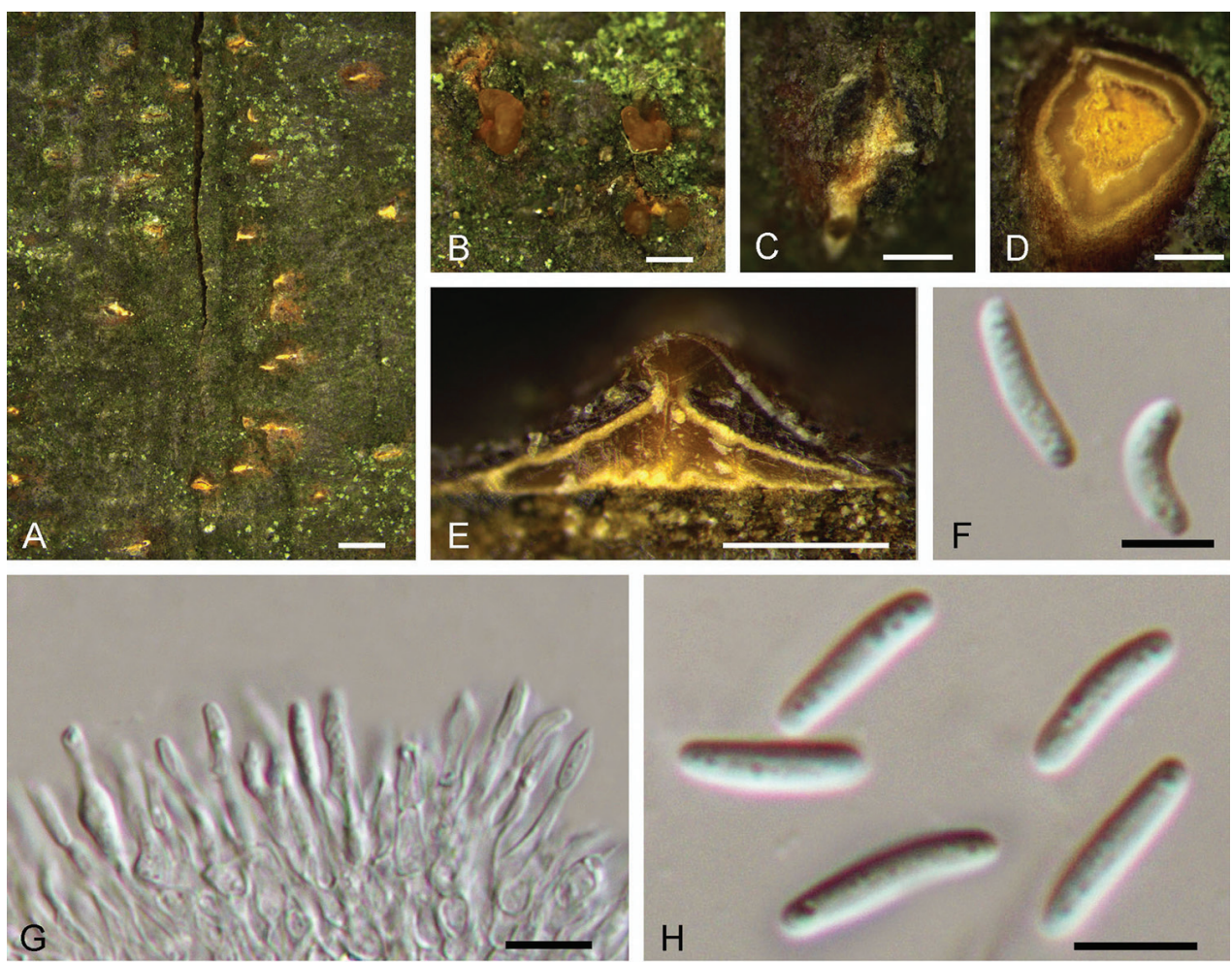

Figure 3. Morphology of Dendrostoma aurorae from Castanea mollissima (BJFC-S1561). A-C Habit of conidiomata on branches $\mathbf{D}$ Transverse section of conidioma $\mathbf{E}$ Longitudinal section through conidioma F, H Conidia $\mathbf{G}$ Conidiogenous cells. Scale bars: $1 \mathrm{~mm}(\mathbf{A}) ; 0.5 \mathrm{~mm}(\mathbf{B}, \mathbf{C}, \mathbf{E}) ; 0.2 \mathrm{~mm}(\mathbf{D})$; $5 \mu \mathrm{m}(\mathbf{F}, \mathbf{H}) ; 10 \mu \mathrm{m}(\mathbf{G})$.

subcylindrical to ampulliform, 4-15 × 2.5-4 $\mu \mathrm{m}$. Conidia hyaline, aseptate, smooth, multiguttulate, thin-walled, ellipsoid to fusoid, straight to curved, (7.2-)8.1-9.8($10.3) \times(2.1-) 2.3-2.6(-2.8) \mu \mathrm{m}, 1 / \mathrm{w}=(2.7-) 3.2-4.1(-4.2)(\mathrm{n}=50)$.

Culture characters. On PDA, cultures are initially white, becoming isabelline after 2 weeks. The colonies are flat with irregular edge; texture uniform within 1 month at $25^{\circ} \mathrm{C}$ in the dark.

Additional specimen examined. CHINA. Shaanxi Province: Lan'gao County, chestnut plantation, 32 $13^{\prime} 43^{\prime \prime} \mathrm{N}, 109^{\circ} 00^{\prime} 44^{\prime \prime E}, 1820 \mathrm{~m}$ a.s.l., on branches of Castanea mollissima, 3 Jul. 2017, N. Jiang, living culture CFCC 52754 (BJFC-S1562).

Notes. Dendrostoma aurorae was discovered on stems of dying chestnut trees and appears morphologically similar to the chestnut blight pathogen, Cryphonectria parasitica. However, these two diaporthalean pathogens can be distinguished by the existence of a central column inside the conidiomata of Dendrostoma aurorae. In the genus Dendrostoma, $D$. aurorae differs from $D$. chinensis and $D$. shandongense by the existence of an obvious central column. 


\section{Dendrostoma castaneae C.M. Tian \& N. Jiang, sp. nov. MycoBank: MB826796 \\ Figure 4}

Diagnosis. Dendrostoma castaneae is distinguished from the phylogenetically closely related species $D$. castaneicola by its narrower conidia.

Holotype. CHINA. Hebei Province: Xinglong County, chestnut plantation, $40^{\circ} 21^{\prime} 44^{\prime \prime N}, 117^{\circ} 51^{\prime} 29^{\prime \prime E}, 256 \mathrm{~m}$ a.s.l., on branches of Castanea mollissima, 27 Apr. 2018, N. Jiang \& C.M. Tian (holotype: BJFC-S1553; ex-type culture: CFCC 52745).

Etymology. Castaneae, referring to the host genus, Castanea.

Description. Sexual morph not observed. Asexual morph: Conidiomata pycnidial, pulvinate, occurring separately, bright yellow to orange, immersed in bark, 400-600 $\mu \mathrm{m}$ high, 900-2200 $\mu \mathrm{m}$ diam.; wall of several layers of brown textura angularis; central column beneath the disc irregular, pale yellow. Conidiophores reduced to conidiogenous cells. Conidiogenous cells lining the inner walls of the cavity, hyaline, smooth, subcylindrical to ampulliform, 3-10 × 2-3.5 $\mu \mathrm{m}$. Conidia hyaline, aseptate, smooth, multiguttulate, thin-walled, ellipsoid, straight to curved, (9.3-)10.4-12.3(-13.3) $\times$ $(2.1-) 2.2-2.7(-2.9) \mu \mathrm{m}, \mathrm{l} / \mathrm{w}=(3.4-) 4.2-5.2(-5.9)(\mathrm{n}=50)$.

Culture characters. On PDA, cultures are initially white, exhibiting grey after 2 weeks. Colonies are flat with irregular edge; texture initially uniform, producing concentric circles with faint orange conidiomata distributed outside the rim within 1 month at $25^{\circ} \mathrm{C}$ in the dark.

Additional specimens examined. CHINA. Hebei Province: Chengde City, Xinglong County, chestnut plantation, 40 $21^{\prime} 44^{\prime \prime} \mathrm{N}, 117^{\circ} 51^{\prime} 29^{\prime \prime} \mathrm{E}, 256 \mathrm{~m}$ a.s.l., on branches of Castanea mollissima, 27 Apr. 2018, N. Jiang \& C.M. Tian, living culture CFCC 52748 (BJFC-S1556); Hebei Province: Chengde City, Xinglong County, chestnut plantation, $40^{\circ} 21^{\prime} 44^{\prime \prime N}, 117^{\circ} 51^{\prime} 29^{\prime \prime} \mathrm{E}, 256 \mathrm{~m}$ a.s.l., on branches of Castanea mollissima, 27 Apr. 2018, N. Jiang \& C.M. Tian, living culture CFCC 52751 (BJFC-S1557); Hebei Province: Chengde City, Xinglong County, chestnut plantation, $40^{\circ} 21^{\prime} 44^{\prime \prime N}, 117^{\circ} 51^{\prime} 29^{\prime \prime E}, 256 \mathrm{~m}$ a.s.l., on branches of Castanea mollissima, 27 Apr. 2018, N. Jiang \& C.M. Tian, living culture CFCC 52747 (BJFC-S1559); Hebei Province: Chengde City, chestnut plantation, $40^{\circ} 37^{\prime} 39^{\prime \prime N}, 118^{\circ} 27^{\prime} 22^{\prime \prime} \mathrm{E}, 256 \mathrm{~m}$ a.s.l., on branches of Castanea mollissima, 28 Apr. 2018, N. Jiang \& C.M. Tian, living culture CFCC 52750 (BJFC-S1558); Hebei Province: Chengde City, chestnut plantation, $40^{\circ} 37^{\prime} 39^{\prime \prime N}, 118^{\circ} 27^{\prime} 22^{\prime \prime E}, 256 \mathrm{~m}$ a.s.l., on branches of Castanea mollissima, 28 Apr. 2018, N. Jiang \& C.M. Tian, living culture CFCC 52752 (BJFC-S1560); Tianjin City: Jizhou District, chestnut plantation, $40^{\circ} 06^{\prime} 33^{\prime \prime N}$, 117\%42'45"E, 185 m a.s.l., on branches of Castanea mollissima, 25 Apr. 2018, N. Jiang \& C.M. Tian, living culture CFCC 52749 (BJFC-S1554); Tianjin City: Jizhou District, chestnut plantation, $40^{\circ} 06^{\prime} 33^{\prime \prime N}, 117^{\circ} 42^{\prime} 45^{\prime} \mathrm{E}, 185 \mathrm{~m}$ a.s.l., on branches of Castanea mollissima, 25 Apr. 2018, N. Jiang \& C.M. Tian, living culture CFCC 52746 (BJFC-S1555).

Notes. Dendrostoma castaneae is the most common species in this genus occurring on the host Castanea mollissima in China and is associated with canker symptoms on stems and branches. As shown in Fig 2, Dendrostoma castaneae is the closest relative of 

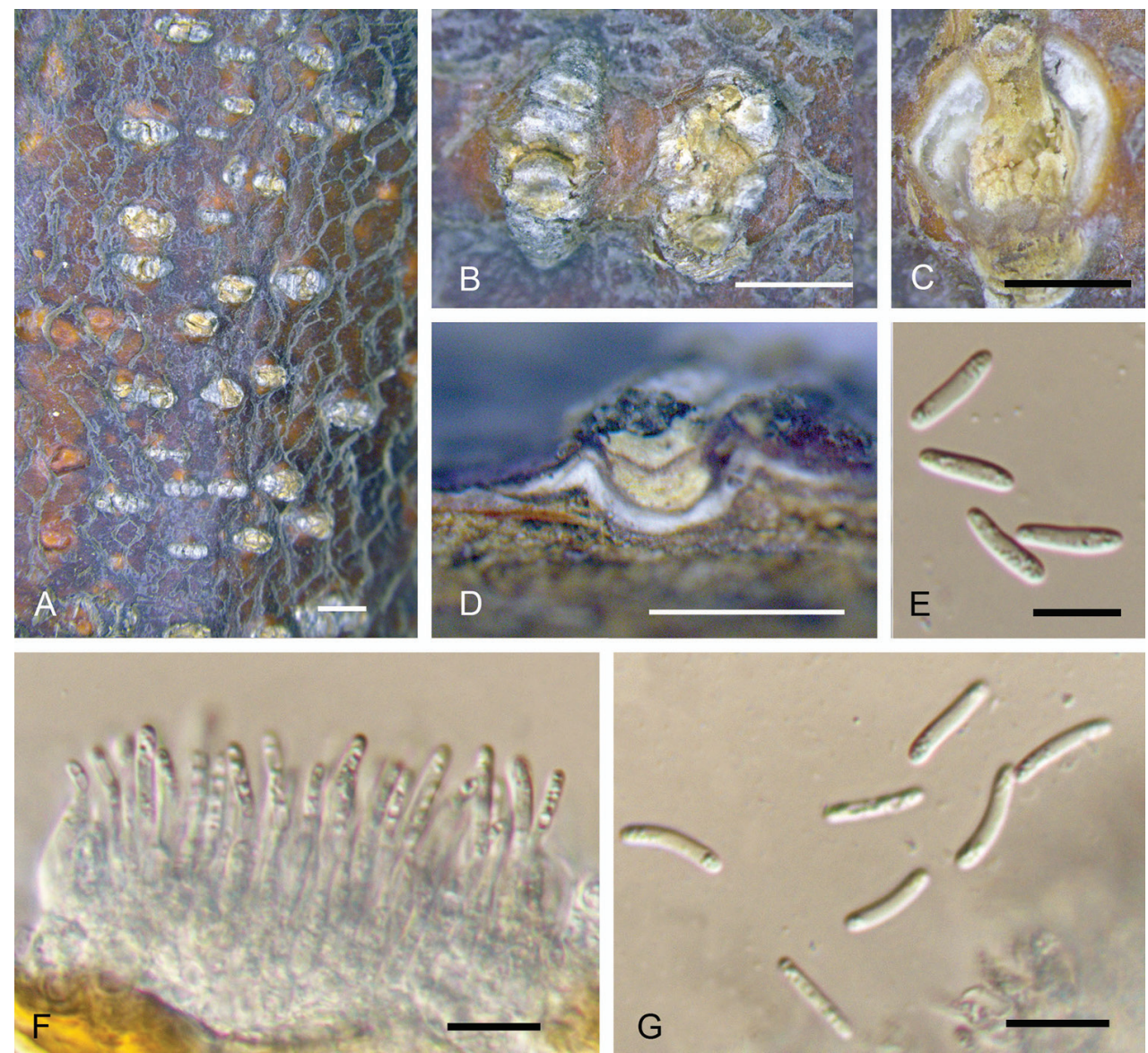

Figure 4. Morphology of Dendrostoma castaneae from Castanea mollissima (BJFC-S1553). A, B Habit of conidiomata on branches $\mathbf{C}$ Transverse section of conidioma $\mathbf{D}$ Longitudinal section through conidioma E, G Conidia F Conidiogenous cells. Scale bars: $1 \mathrm{~mm}(\mathbf{A}-\mathbf{D}) ; 10 \mu \mathrm{m}(\mathbf{E}-\mathbf{G})$.

D. castaneicola; however, they can be distinguished by conidial width $(2.2-2.7 \mu \mathrm{m}$ in D. castaneae vs. $3.2-3.8 \mu \mathrm{m}$ in D. castaneicola).

\section{Dendrostoma castaneicola C.M. Tian \& N. Jiang, sp. nov.}

MycoBank: MB826797

Figure 5

Diagnosis. Dendrostoma castaneicola differs from the two phylogenetically closely related species, D. castaneae and D. shaanxiense, by its white central column.

Holotype. CHINA. Hebei Province: Chengde City, chestnut plantation, $40^{\circ} 24^{\prime} 32^{\prime \prime N}, 117^{\circ} 28^{\prime} 55^{\prime} \mathrm{E}, 262 \mathrm{~m}$ a.s.l., on branches of Castanea mollissima, 28 Apr. 2018, N. Jiang \& C.M. Tian (holotype: BJFC-S1551; ex-type culture: CFCC 52743).

Etymology. Castaneicola, referring to the host genus, Castanea. 

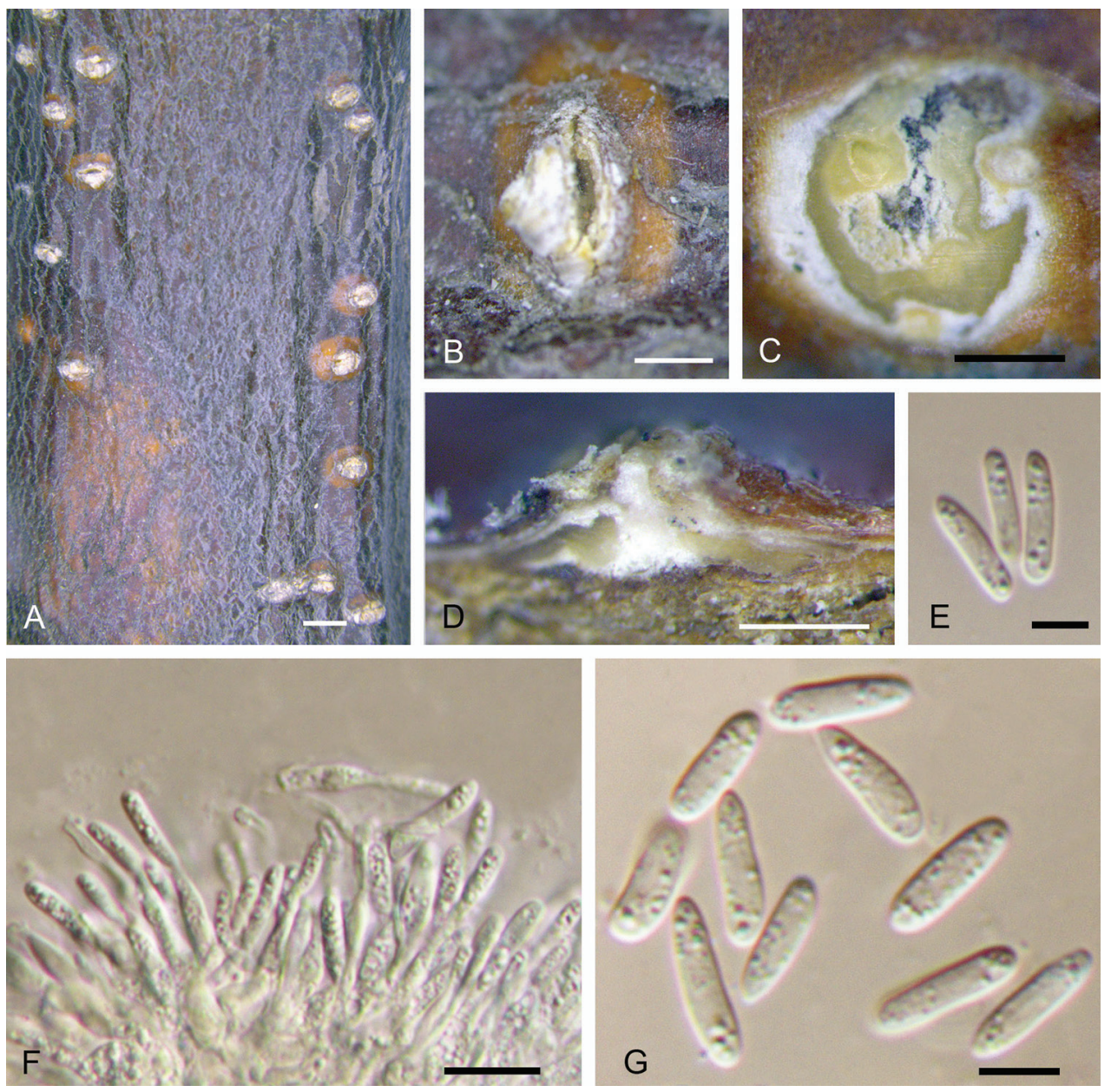

Figure 5. Morphology of Dendrostoma castaneicola from Castanea mollissima (BJFC-S1551). A, B Habit of conidiomata on branches $\mathbf{C}$ Transverse section of conidioma $\mathbf{D}$ Longitudinal section through conidio$\mathrm{ma} \mathbf{E}, \mathbf{G}$ Conidia $\mathbf{F}$ Conidiogenous cells. Scale bars: $1 \mathrm{~mm}(\mathbf{A}) ; 0.5 \mathrm{~mm}(\mathbf{B}-\mathbf{D}) ; 5 \mu \mathrm{m}(\mathbf{E}, \mathbf{G}) ; 10 \mu \mathrm{m}(\mathbf{F})$.

Description. Sexual morph not observed. Asexual morph: Conidiomata pycnidial, conical to pulvinate, occurring separately, reddish-orange, semi-immersed in bark, 300-550 $\mu \mathrm{m}$ high, 900-1600 $\mu \mathrm{m}$ diam.; wall of several layers of faint yellow textura angularis; central column beneath the disc more or less conical, white. Conidiophores reduced to conidiogenous cells. Conidiogenous cells lining the inner walls of the cavity, hyaline, smooth, subcylindrical to ampulliform, 5-14 × 2-3.5 $\mu \mathrm{m}$. Conidia hyaline, aseptate, smooth, multiguttulate, thin-walled, ellipsoid to fusoid, straight, (9.3-)10.5$12.8(-13.8) \times(3.1-) 3.2-3.8(-4.1) \mu \mathrm{m}, 1 / \mathrm{w}=(2.3-) 3-4(-4.4)(\mathrm{n}=50)$.

Culture characters. On PDA, cultures are initially white, becoming black after 2 weeks. The colonies are flat with irregular edge; texture uniform, producing a circle with faint orange conidiomata distributed along the edge of the circle within 1 month at $25^{\circ} \mathrm{C}$ in the dark. 
Additional specimen examined. CHINA. Hebei Province: Chengde City, Xinglong County, chestnut plantation, 40²1'44"N, 117 51'29"E, $256 \mathrm{~m}$ a.s.l., on branches of Castanea mollissima, 27 Apr. 2018, N. Jiang \& C.M. Tian, living culture CFCC 52744 (BJFC-S1552).

Notes. Dendrostoma castaneicola, D. castaneae and D. shaanxiense comprise three closely related pathogen species causing chestnut canker diseases in China, all three species occurring on Castanea mollissima. They differ with regard to conidiomatal characteristics, including conidial dimensions (Table 2) and the central column colour (pale yellow central column in D. castaneae vs. white in D. castaneicola vs. bright yellow in D. shaanxiense). Additionally, Dendrostoma shaanxiense was only discovered in the Shaanxi Province, whereas D. castaneae and D. castaneicola were both distributed in Hebei Province.

\section{Dendrostoma chinense C.M. Tian \& N. Jiang, sp. nov. MycoBank: MB826798}

Figure 6

Diagnosis. Dendrostoma chinense differs from $D$. shandongense by the appearance of conidiomata and is again similar to $D$. shandongense in its conidial characteristics.

Holotype. CHINA. Shandong Province: Rizhao City, Donggang District, chestnut plantation, $35^{\circ} 42^{\prime} 28^{\prime \prime} \mathrm{N}, 119^{\circ} 46^{\prime} 23^{\prime \prime} \mathrm{E}, 452 \mathrm{~m}$ a.s.l., on branches of Castanea mollissima, 14 Apr. 2017, N. Jiang (holotype: BJFC-S1563; ex-type culture: CFCC 52755).

Etymology. Chinense, referring to the country, China.

Description. Sexual morph not observed. Asexual morph: Conidiomata pycnidial, spherical, occurring separately, black, semi-immersed in bark, 250-450 $\mu \mathrm{m}$ high, 600$850 \mu \mathrm{m}$ diam.; wall of several layers of white textura angularis. Conidiophores reduced to conidiogenous cells. Conidiogenous cells lining the inner walls of the cavity, hyaline, smooth, ampulliform, 7-14 × 1-2.5 $\mu \mathrm{m}$. Conidia hyaline, aseptate, smooth, multiguttulate or not, thin-walled, fusoid to ellipsoid, apex acutely rounded, base truncate, (6.9-)7.7-9.1(-9.7) × (3.3-)3.4-3.7(-3.9) $\mu \mathrm{m}, 1 / \mathrm{w}=(1.9-) 2.2-2.6(-2.7)(\mathrm{n}=50)$.

Culture characters. On PDA, cultures are initially white, becoming olive green in the outer zone after 2 weeks. Colonies are flat with a regular edge; texture uniform within 1 month at $25^{\circ} \mathrm{C}$ in the dark.

Additional specimens examined. CHINA. Shandong Province: Rizhao City, Donggang District, chestnut plantation, 3542'28"N, 11946'23"E, 452 m a.s.l., on branches of Castanea mollissima, 14 Apr. 2017, N. Jiang, living culture CFCC 52756 (BJFCS1564); Hebei Province: Chengde City, chestnut plantation, 40²4'32"N, 117²8'55"E, 262 m a.s.l., on branches of Castanea mollissima, 29 Apr. 2018, N. Jiang \& C.M. Tian, living culture CFCC 52757 (BJFC-S1565); Hebei Province: Chengde City, chestnut plantation, $40^{\circ} 24^{\prime} 32^{\prime \prime} \mathrm{N}, 117^{\circ} 28^{\prime} 55^{\prime \prime} \mathrm{E}, 262 \mathrm{~m}$ a.s.l., on branches of Castanea mollissima, 29 Apr. 2018, N. Jiang \& C.M. Tian, living culture CFCC 52757 (BJFC-S1566).

Notes. Dendrostoma chinense and $D$. shandongense have been occasionally discovered on the same branches and share similar conidial shape and dimensions. However, 

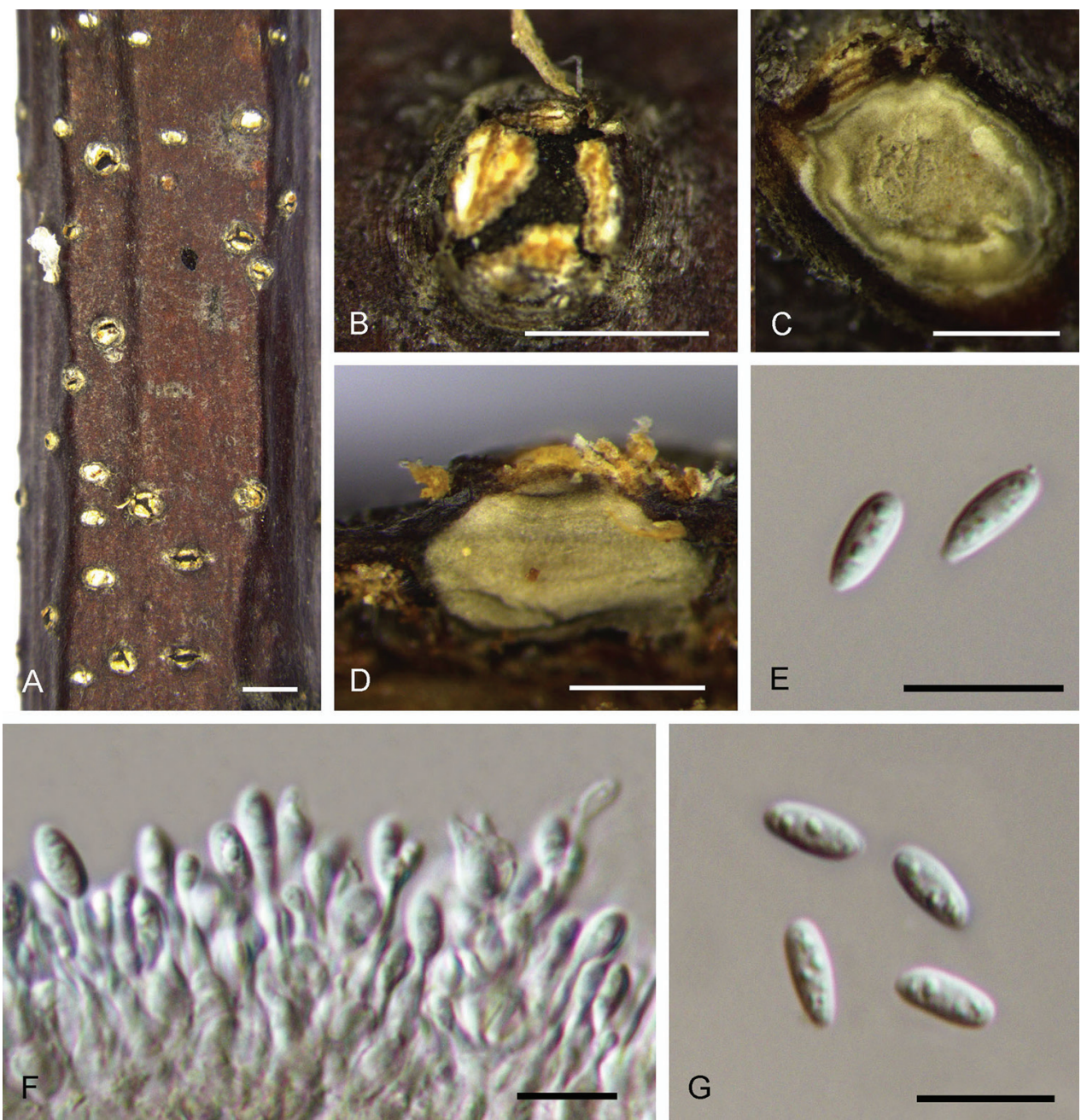

Figure 6. Morphology of Dendrostoma chinense from Castanea mollissima (BJFC-S1563). A, B Habit of conidiomata on branches $\mathbf{C}$ Transverse section of conidioma $\mathbf{D}$ Longitudinal section through conidioma E, G Conidia F Conidiogenous cells. Scale bars: $1 \mathrm{~mm}(\mathbf{A}) ; 0.5 \mathrm{~mm}$ (B-D); $10 \mu \mathrm{m}(\mathbf{E}-\mathbf{G})$.

the conidiomatal appearance of these two species is quite different (black conidiomata in Dendrostoma chinense vs. orange conidiomata in D. shandongense).

\section{Dendrostoma dispersum C.M. Tian \& N. Jiang, sp. nov.}

MycoBank: MB826799

Figure 7

Diagnosis. Dendrostoma dispersum can be distinguished from the phylogenetically closely related D. mali and D. quercinum based on its conidial dimensions. 


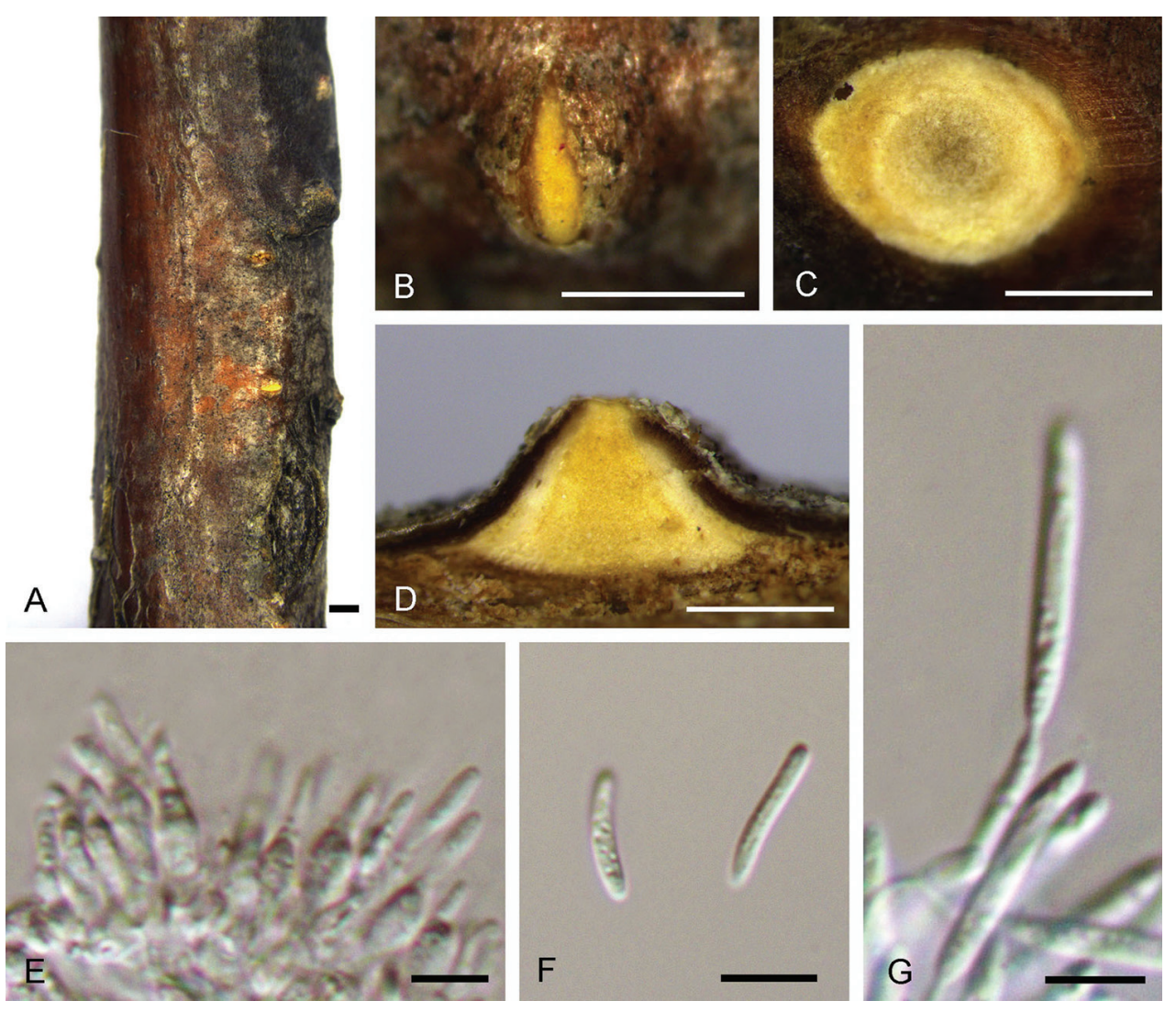

Figure 7. Morphology of Dendrostoma dispersum from Quercus sp. (BJFC-S1537). A, B Habit of conidiomata on branches $\mathbf{C}$ Transverse section of conidioma D Longitudinal section through conidioma $\mathbf{E}, \mathbf{G}$ Conidiogenous cells $\mathbf{F}$ Conidia. Scale bars: $1 \mathrm{~mm}(\mathbf{A}) ; 0.5 \mathrm{~mm}(\mathbf{B}-\mathbf{D}) ; 10 \mu \mathrm{m}(\mathbf{E}, \mathbf{F}), 5 \mu \mathrm{m}(\mathbf{G})$.

Holotype. CHINA. Shaanxi Province: Beijing City: Mentougou District, Xiaolongmen Forest Park, 3955'52"N, 11545'15"E, 1670 m a.s.l., on branches of Quercus sp., 15 Aug. 2017, N. Jiang \& X.L. Fan (holotype: BJFC-S1537; ex-type culture: CFCC 52730).

Etymology. Dispersum, referring to the conidiomata scattered on the bark surface.

Description. Sexual morph not observed. Asexual morph: Conidiomata pycnidial, conical to spherical, occurring separately, bright yellow, semi-immersed in bark, 500 $800 \mu \mathrm{m}$ high, $900-1500 \mu \mathrm{m}$ diam.; wall of several layers of bright yellow textura angularis; central column beneath the disc conical, bright yellow. Conidiophores reduced to conidiogenous cells. Conidiogenous cells lining the inner walls of the cavity, hyaline, smooth, subcylindrical to ampulliform, $6-15 \times 2.5-5 \mu \mathrm{m}$. Conidia hyaline, aseptate, smooth, multiguttulate, thin-walled, ellipsoid to fusoid, straight to curved, (10.9)11.1-12.2(-12.8) × (1.9-)2-2.3(-2.4) $\mu \mathrm{m}, 1 / \mathrm{w}=(4.8-) 4.9-5.9(-6.3)(\mathrm{n}=50)$.

Culture characters. On PDA, cultures are initially white, becoming faint yellow after 2 weeks. The colonies are flat with regular edge; texture uniform, producing concentric circles within 1 month at $25^{\circ} \mathrm{C}$ in the dark. 
Additional specimen examined. CHINA. Beijing City: Yanqing District, Yudu Mountain, 40 $53^{\prime} 48^{\prime \prime} \mathrm{N}, 115^{\circ} 54^{\prime} 48^{\prime \prime E}, 840 \mathrm{~m}$ a.s.l., on branches of Quercus sp., 12 Mar. 2018, N. Jiang, X.L. Fan, Y.M. Liang \& C.M. Tian, living culture CFCC 52731 (BJFC-S1538).

Notes. Dendrostoma dispersum is phylogenetically close to D. mali and D. quercinum (Fig. 2). Conidial dimensions of Dendrostoma mali and D. quercinum were described from PDA plates (Fan et al. 2018) and D. dispersum can be differentiated from $D$. mali by having much longer conidia (11.1-12.2 $\mu \mathrm{m}$ in $D$. dispersum vs. 3-4.5 $\mu \mathrm{m}$ in $D$. mali) and from $D$. quercinum by narrower conidia $(2-2.3 \mu \mathrm{m}$ in $D$. dispersum vs. 2.5-3 $\mu \mathrm{m}$ in D. quercinum).

\section{Dendrostoma parasiticum C.M. Tian \& N. Jiang, sp. nov. MycoBank: MB826822}

Figure 8

Diagnosis. Dendrostoma parasiticum is distinguished from $D$. quercus by its shorter and narrower conidia.

Holotype. CHINA. Shaanxi Province: Shangluo City, Zhashui County, Longtougou Village, 3339'27"N, 109 $07^{\circ} 15^{\prime \prime} \mathrm{E}, 2504 \mathrm{~m}$ a.s.1., on branches of Quercus wutaishanica, 8 Jul. 2017, N. Jiang (holotype: BJFC-S1570; ex-type culture: CFCC 52762).

Etymology. Parasiticum, referring to the fungus causing canker diseases on different hosts.

Description. Sexual morph not observed. Asexual morph: Conidiomata pycnidial, conical to spherical, occurring separately, yellow, semi-immersed in bark, 350-600 $\mu \mathrm{m}$ high, 1000-1800 $\mu \mathrm{m}$ diam.; wall of several layers of bright yellow textura angularis; central column beneath the disc conical, bright yellow. Conidiophores reduced to conidiogenous cells. Conidiogenous cells lining the inner walls of the cavity, hyaline, smooth, subcylindrical to ampulliform, 7-12 × 2-3.5 $\mu \mathrm{m}$. Conidia hyaline, aseptate, smooth, multiguttulate, thin-walled, fusoid, straight, (9.2-)9.3-11.7(-13.6) $\times(2.7-) 2.8-3.3(-$ 3.6) $\mu \mathrm{m}, \mathrm{l} / \mathrm{w}=(2.7-) 3-3.9(-4.2)(\mathrm{n}=50)$.

Culture characters. On PDA, cultures are initially white, becoming dark orange after 2 weeks. The colonies are flat with irregular edge; texture uniform, producing concentric circles within 1 month at $25^{\circ} \mathrm{C}$ in the dark.

Additional specimens examined. CHINA. Shaanxi Province: Shangluo City, Zhashui County, chestnut plantation, 3339'27"N, 10907'15"E, $2504 \mathrm{~m}$ a.s.l., on branches of Castanea mollissima, 8 Jul. 2017, N. Jiang, living culture CFCC 52762 (BJFC-S1569); Shaanxi Province: Ankang City, Xiangxidong Park, 3240'32"N, $109^{\circ} 18^{\prime} 57^{\prime \prime E}, 2504 \mathrm{~m}$ a.s.l., on branches of Castanea mollissima, 29 Jun. 2017, N. Jiang, living culture CFCC 52763 (BJFC-S1571); Beijing City: Mentougou District, Xiaolongmen Forest Park, 39¹7'25"N, 11545'23"E, 452 m a.s.l., on branches of Castanea mollissima, 17 Aug. 2017, N. Jiang \& X.L. Fan, living culture CFCC 52764 (BJFC-S1572); Beijing City: Yanqing District, Yudu Mountain, 4053'48"N, 

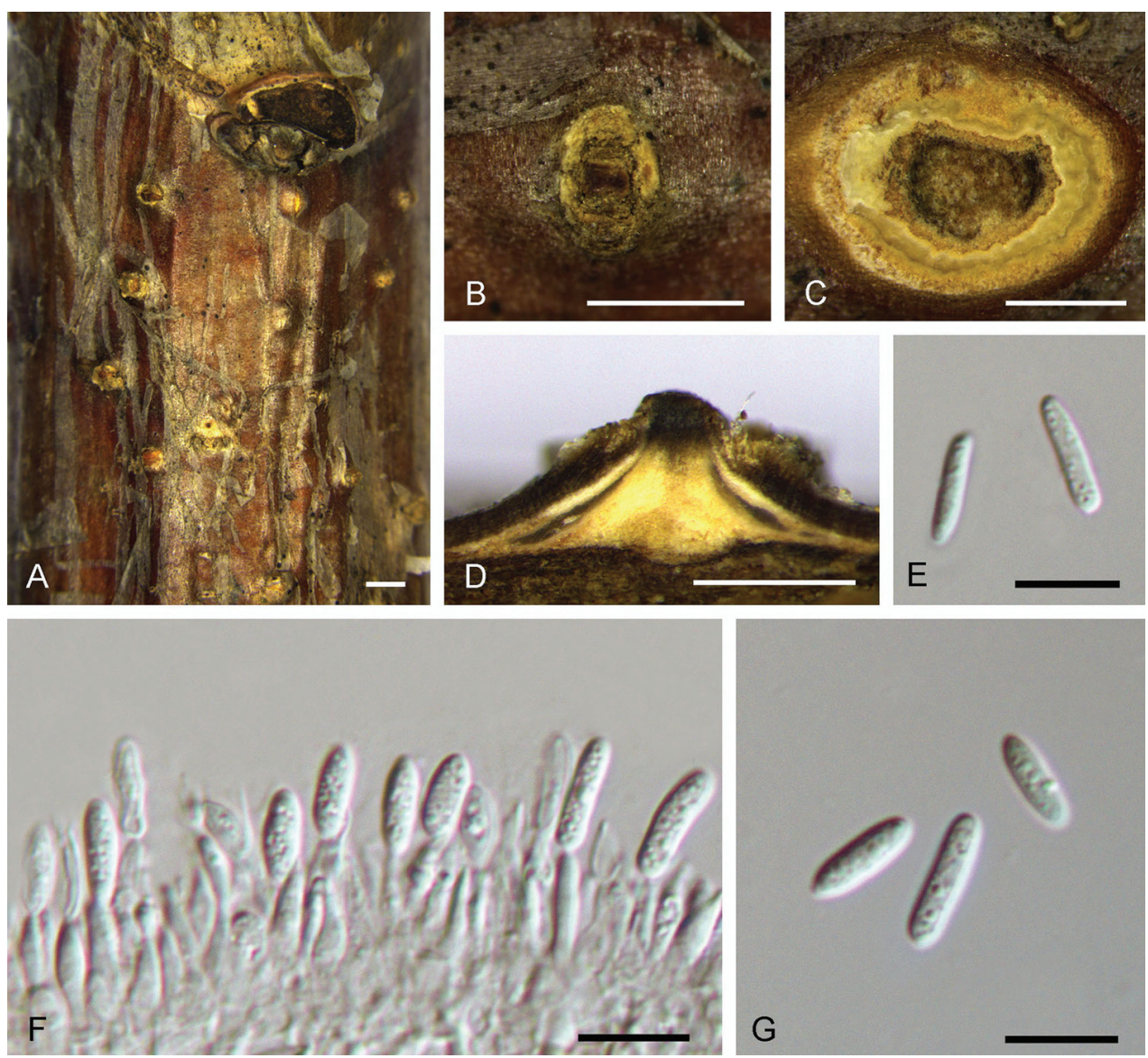

Figure 8. Morphology of Dendrostoma parasiticum from Quercus wutaishanica (BJFC-S1570). A, B Habit of conidiomata on branches $\mathbf{C}$ Transverse section of conidioma $\mathbf{D}$ Longitudinal section through conidioma E, G Conidia F Conidiogenous cells. Scale bars: $2 \mathrm{~mm}(\mathbf{A}) ; 1 \mathrm{~mm}(\mathbf{B}) ; 0.5 \mathrm{~mm}(\mathbf{C}, \mathbf{D}) ; 10 \mu \mathrm{m}(\mathbf{E}-\mathbf{G})$.

$115^{\circ} 54^{\prime} 48^{\prime \prime E}, 840 \mathrm{~m}$ a.s.l., on branches of Quercus aliena, 12 Mar. 2017, N. Jiang, X.L. Fan, Y.M. Liang \& C.M. Tian, living culture CFCC 52765 (BJFC-S1573); Hebei Province: Chengde City, chestnut plantation, 40²4'32"N, 117²28'55"E, $262 \mathrm{~m}$ a.s.l., on branches of Quercus aliena var. acutiserrata, 15 Oct. 2017, N. Jiang, living culture CFCC 52766 (BJFC-S1574).

Notes. Dendrostoma parasiticum constitutes a widely distributed species occurring on several Fagaceae tree species including Castanea mollissima, Quercus aliena, Q. aliena var. acuteserrata and $Q$. wutaishansea. Dendrostoma parasiticum appears to be associated with tree dieback, canker and even tree death, although its pathogenicity remains unproven. Dendrostoma parasiticum is close to D. quercus in the phylogram (Fig. 2), but differs from D. quercus with shorter (9.3-11.7 $\mu \mathrm{m}$ in D. parasiticum vs. 13.3-16.1 $\mu \mathrm{m}$ in D. quercus) and narrower $(2.8-3.3 \mu \mathrm{m}$ in D. parasiticum vs. 3.5-4.2 $\mu \mathrm{m}$ in $D$. quercus) conidia. 


\section{Dendrostoma qinlingense C.M. Tian \& N. Jiang, sp. nov.}

MycoBank: MB826823

Figure 9

Diagnosis. Dendrostoma qinlingense produces the largest conidia amongst known species of the genus.

Holotype. CHINA. Baoji City, Mei County, Taibai Mountain, $34^{\circ} 15^{\prime} 43^{\prime \prime}$, $107^{\circ} 88^{\prime} 42^{\prime \prime E}, 2752 \mathrm{~m}$ a.s.l., on branches of Quercus wutaishanica, 13 Jul. 2017, N. Jiang (holotype: BJFC-S1539; ex-type culture: CFCC 52732).

Etymology. Qinlingense, referring to the Qinling Mountain.

Description. Sexual morph not observed. Asexual morph: Conidiomata pycnidial, conical to pulvinate, occurring separately, dark yellow, semi-immersed in bark, 400$700 \mu \mathrm{m}$ high, 1100-1600 $\mu \mathrm{m}$ diam.; wall of several layers of bright yellow textura angularis; central column beneath the disc conical, dark orange. Conidiophores reduced to conidiogenous cells. Conidiogenous cells lining the inner walls of the cavity, hyaline,

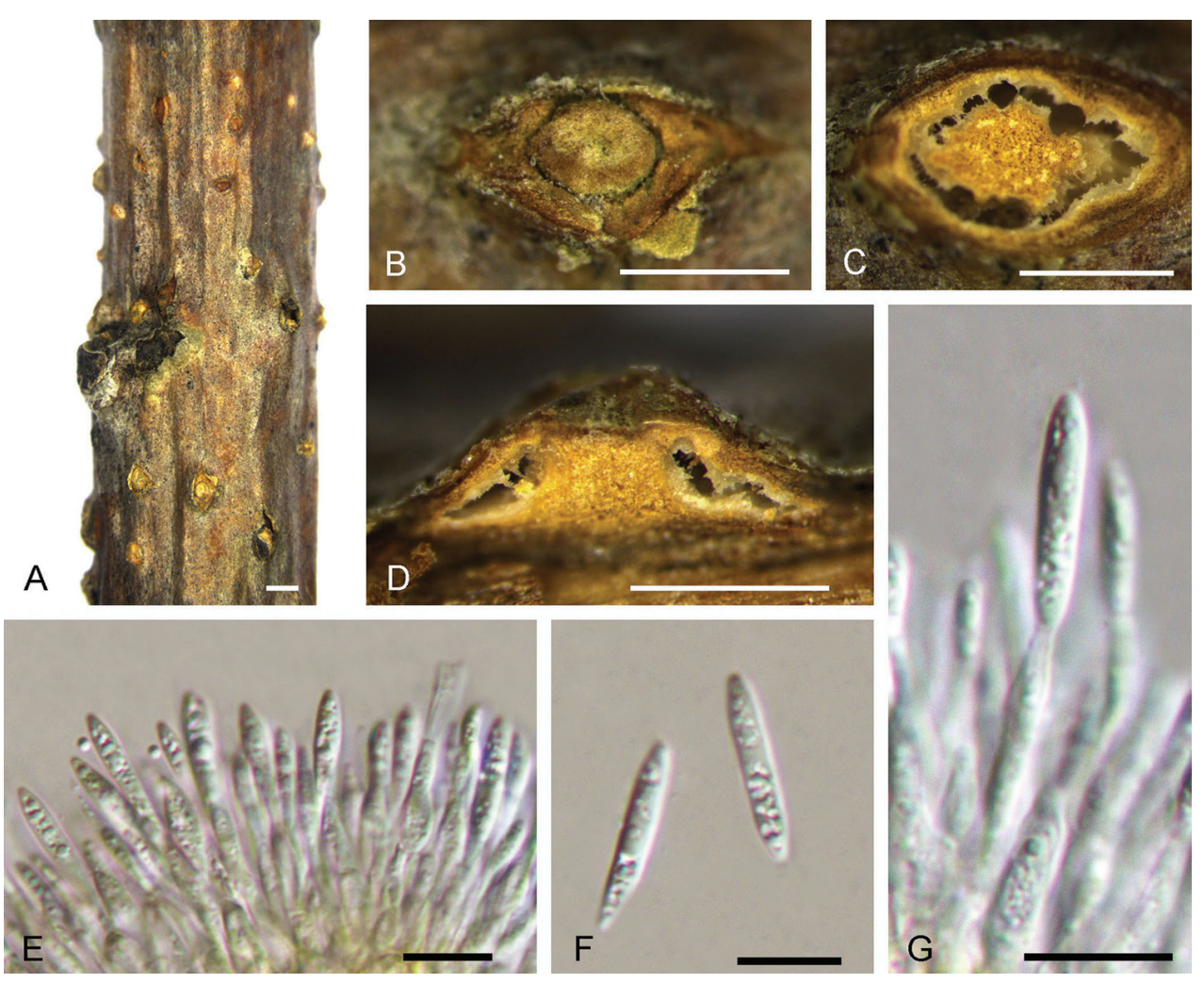

Figure 9. Morphology of Dendrostoma qinlingense from Quercus wutaishanica (BJFC-S1539). A, B Habit of conidiomata on branches $\mathbf{C}$ Transverse section of conidioma $\mathbf{D}$ Longitudinal section through conidioma E, G Conidiogenous cells $\mathbf{F}$ Conidia. Scale bars: $1 \mathrm{~mm}(\mathbf{A}) ; 0.5 \mathrm{~mm}(\mathbf{B}-\mathbf{D}) ; 10 \mu \mathrm{m}(\mathbf{E}-\mathbf{G})$. 
smooth, ampulliform, 6-22 × 2-3.5 $\mu \mathrm{m}$. Conidia hyaline, aseptate, smooth, multiguttulate, thin-walled, fusoid, straight, (15.6-)16-18(-18.6) $\times(3.1-) 3.3-3.7(-3.8) \mu \mathrm{m}$, $\mathrm{l} / \mathrm{w}=(4.2-) 4.4-5.2(-5.8)(\mathrm{n}=50)$.

Culture characters. On PDA, cultures are initially white, exhibiting light grey after 2 weeks. The colonies are flat with irregular edge; texture uniform, producing concentric circles with sparse conidiomata irregularly distributed on the centre of the plate within 1 month at $25^{\circ} \mathrm{C}$ in the dark.

Additional specimen examined. CHINA. Shaanxi Province: Baoji City, Mei County, Taibai Mountain, 34 $15^{\prime} 43^{\prime \prime} \mathrm{N}, 107^{\circ} 88^{\prime} 42^{\prime \prime} \mathrm{E}, 2752 \mathrm{~m}$ a.s.l., on branches of Quercus aliena var. acutiserrata, 13 Jul. 2017, N. Jiang, living culture CFCC 52733 (BJFC-S1540).

Notes. Dendrostoma qinlingense was discovered on two Quercus species on the Qinling Mountain in northwest China. This species is phylogenetically related to Dendrostoma osmanthi on Osmanthus fragrans. However, Dendrostoma qinlingense differs from D. osmanthi by much larger conidia $(16-18 \times 3.3-3.7 \mu \mathrm{m}$ in D. qinlingense vs. $7.5-10$ $\times 2-2.5 \mu \mathrm{m}$ in D. osmanthi).

\section{Dendrostoma quercus C.M. Tian \& N. Jiang, sp. nov. MycoBank: MB826824 \\ Figure 10}

Diagnosis. Dendrostoma quercus is recognised by the existence of dimorphic conidia, which is unique in the genus.

Holotype. CHINA. Hebei Province: Qinhuangdao City, $\mathrm{Zu}$ Mountain, $40^{\circ} 14^{\prime} 13^{\prime \prime N}, 119^{\circ} 43^{\prime} 28^{\prime \prime E}, 1125$ m a.s.l., on branches of Quercus sp., 2 May 2018, N. Jiang \& C.M. Tian (holotype: BJFC-S1547; ex-type culture: CFCC 52739).

Etymology. Quercus, referring to the host genus, Quercus.

Description. Sexual morph: Pseudostromata erumpent, consisting of an inconspicuous ectostromatic disc, semi-immersed to superficial, causing a pustulate bark surface, 1000-1500 $\mu \mathrm{m}$ diam. Ectostromatic disc flat or concave, pale brown to brown, sometimes concealed by ostioles, surrounded by bark flaps, 400-800 $\mu \mathrm{m}$ diam.; central column yellowish to brownish. Stromatic zones lacking. Perithecia conspicuous, umber to fuscous black, 350-500 $\mu \mathrm{m}$ diam. Ostioles 5-8 per disc, flat in the disc or sometimes slightly projecting, cylindrical, covered by an orange, umber to fuscous black crust, 60 $80 \mu \mathrm{m}$ diam. Paraphyses slightly deliquescent. Asci fusoid to slightly fusiform, 8-spored, ascospores regularly disposed, with an apical ring, 55-65 × 8-11 $\mu \mathrm{m}$. Ascospores hyaline, fusoid to cylindrical, smooth, often containing one guttule per cell to multiguttulate, symmetrical to asymmetrical, straight curved, bicellular, (13.4-)13.8-15.6(-16.6) $\times$ $(5.1-) 5.3-5.8(-5.9) \mu \mathrm{m}, 1 / \mathrm{w}=(2.4-) 2.5-2.8(-2.9)(\mathrm{n}=50)$. Asexual morph: Conidiomata pycnidial, conical, occurring separately, pale yellow, semi-immersed in bark, 700-1000 $\mu \mathrm{m}$ high, 700-950 $\mu \mathrm{m}$ diam.; wall of several layers of pale yellow textura angularis; central column beneath the disc conical, yellow. Conidiophores reduced to conidiogenous cells. Conidiogenous cells lining the inner walls of the cavity, hyaline, 

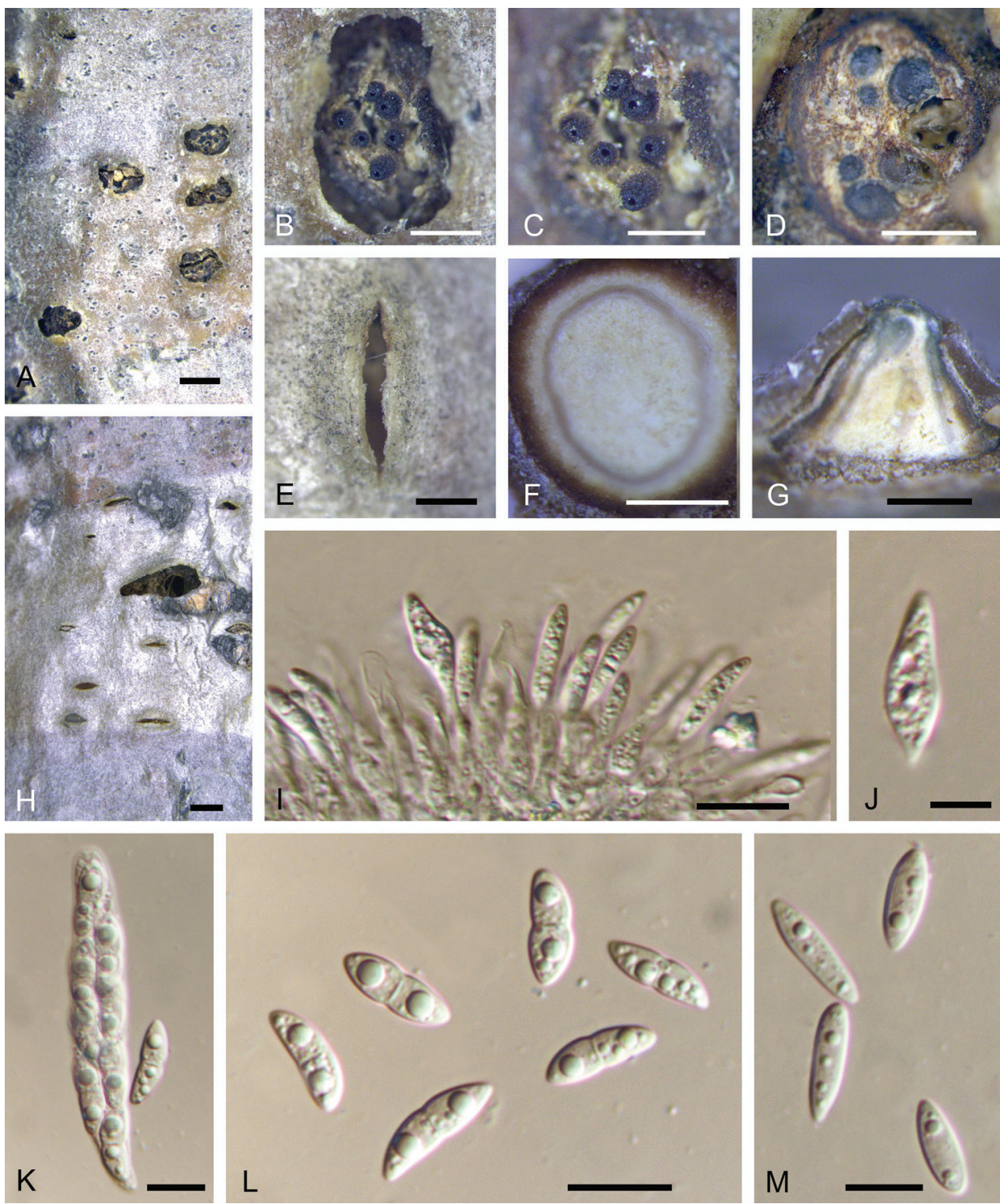

Figure 10. Morphology of Dendrostoma quercus from Quercus sp. (BJFC-S1547). A-C Habit of psedostromata on branches $\mathbf{D}$ Transverse section of pseudostroma $\mathbf{E}, \mathbf{H}$ Habit of conidiomata on branches F Transverse section of conidioma G Longitudinal section through conidioma I Conidiogenous cells producing dimorphic conidia J Secondary conidia $\mathbf{K}$ Asci and ascospores $\mathbf{L}$ Ascospores $\mathbf{M}$ Primary conidia. Scale bars: $1 \mathrm{~mm}(\mathbf{A}, \mathbf{H}) ; 0.5 \mathrm{~mm}(\mathbf{B}-\mathbf{G}) ; 10 \mu \mathrm{m}(\mathbf{I}, \mathbf{K}-\mathbf{M}) ; 5 \mu \mathrm{m}(\mathbf{J})$.

smooth, subcylindrical to ampulliform, 4.5-9 $\times 2-4 \mu \mathrm{m}$. Conidia hyaline, aseptate, smooth, multiguttulate, thin-walled, dimorphic, type one (>99\%) ellipsoid to fusoid, straight to curved, (11-)13.3-16.1(-16.9) $\times(3.4-) 3.5-4.2(-4.5) \mu \mathrm{m}, 1 / \mathrm{w}=(2.6-) 3.3-$ $4.4(-4.9)(\mathrm{n}=50)$; type two $(<1 \%)$ fusoid, apex acutely rounded, $13-16 \times 4-6 \mu \mathrm{m}$. 
Culture characters. On PDA, cultures are initially white, becoming dark grey after 2 weeks. The colonies are flat with irregular edge; texture uniform, producing concentric circles with sparse conidiomata irregularly distributed within 1 month at $25^{\circ} \mathrm{C}$ in the dark.

Additional specimens examined. CHINA. Hebei Province: Qinhuangdao City, Zu Mountain, 40¹4'13"N, 11943'28"E, $1125 \mathrm{~m}$ a.s.l., on branches of Quercus sp., 2 May 2018, N. Jiang \& C.M. Tian, living culture CFCC 52734 (BJFC-S1548); Hebei Province: Qinhuangdao City, Zu Mountain, 40¹4'13"N, 11943'28"E, 1125 m a.s.l., on branches of Quercus sp., 2 May 2018, N. Jiang \& C.M. Tian, living culture CFCC 52735 (BJFC-S1541); Hebei Province: Qinhuangdao City, Zu Mountain, $40^{\circ} 14^{\prime} 13^{\prime \prime} \mathrm{N}, 119^{\circ} 43^{\prime} 28^{\prime \prime E}, 1125 \mathrm{~m}$ a.s.l., on branches of Quercus sp., 2 May 2018, N. Jiang \& C.M. Tian, living culture CFCC 52736 (BJFC-S1542); Hebei Province: Qinhuangdao City, Zu Mountain, 40¹4'13"N, $119^{\circ} 43^{\prime} 28^{\prime \prime E}, 1125 \mathrm{~m}$ a.s.l., on branches of Quercus sp., 2 May 2018, N. Jiang \& C.M. Tian, living culture CFCC 52737 (BJFC-S1543); Hebei Province: Qinhuangdao City, Zu Mountain, 40¹4'13"N, $119^{\circ} 43^{\prime} 28^{\prime \prime E}, 1125 \mathrm{~m}$ a.s.l., on branches of Quercus sp., 2 May 2018, N. Jiang \& C.M. Tian, living culture CFCC 52738 (BJFC-S1544); Hebei Province: Qinhuangdao City, $\mathrm{Zu}$ Mountain, $40^{\circ} 14^{\prime} 13^{\prime \prime N}, 119^{\circ} 43^{\prime} 28^{\prime \prime E}, 1125 \mathrm{~m}$ a.s.l., on branches of Quercus sp., 2 May 2018, N. Jiang \& C.M. Tian, living culture CFCC 52740 (BJFC-S1545).

Notes. Dendrostoma quercus is associated with oak branch cankers and forms both sexual and asexual fruiting structures beneath cankered bark. Within the genus, $D$. quercus produces the second largest conidia, smaller only than those of $D$. qinlingense (Table 2). The presence of dimorphic conidia in Dendrostoma, however, is a feature unique to $D$. quercus.

\section{Dendrostoma shaanxiense C.M. Tian \& N. Jiang, sp. nov.}

MycoBank: MB826825

Figure 11

Diagnosis. Dendrostoma shaanxiense is distinguished from the closely related species $D$. castaneae by smaller $1 / \mathrm{w}$ ratio and from $D$. castaneicola by its narrower conidia.

Holotype. CHINA. Shaanxi Province: Ankang City, Xiangxidong Park, $32^{\circ} 40^{\prime} 32^{\prime \prime N}, 109^{\circ} 18^{\prime} 57^{\prime \prime E}, 1079 \mathrm{~m}$ a.s.l., on branches of Castanea mollissima, $1 \mathrm{Jul}$. 2017, N. Jiang (holotype: BJFC-S1549; ex-type culture: CFCC 52741).

Etymology. Shaanxiense, referring to the Shaanxi Province in China.

Description. Sexual morph not observed. Asexual morph: Conidiomata pycnidial, conical to pulvinate, occurring separately, dark orange, semi-immersed in bark, 350 $650 \mu \mathrm{m}$ high, 1050-1400 $\mu \mathrm{m}$ diam.; wall of several layers of bright yellow textura angularis; central column beneath the disc conical, bright yellow. Conidiophores reduced to conidiogenous cells. Conidiogenous cells lining the inner walls of the cavity, hyaline, smooth, subcylindrical to ampulliform, 5-11 × 2.5-3.5 $\mu \mathrm{m}$. Conidia hyaline, aseptate, smooth, multiguttulate, thin-walled, ellipsoid to fusoid, straight to curved, (8.6-)9.5$11.1(-11.7) \times(2.3-) 2.5-3.1(-3.4) \mu \mathrm{m}, \mathrm{l} / \mathrm{w}=(2.8-) 3.3-4.2(-4.9)(\mathrm{n}=50)$. 

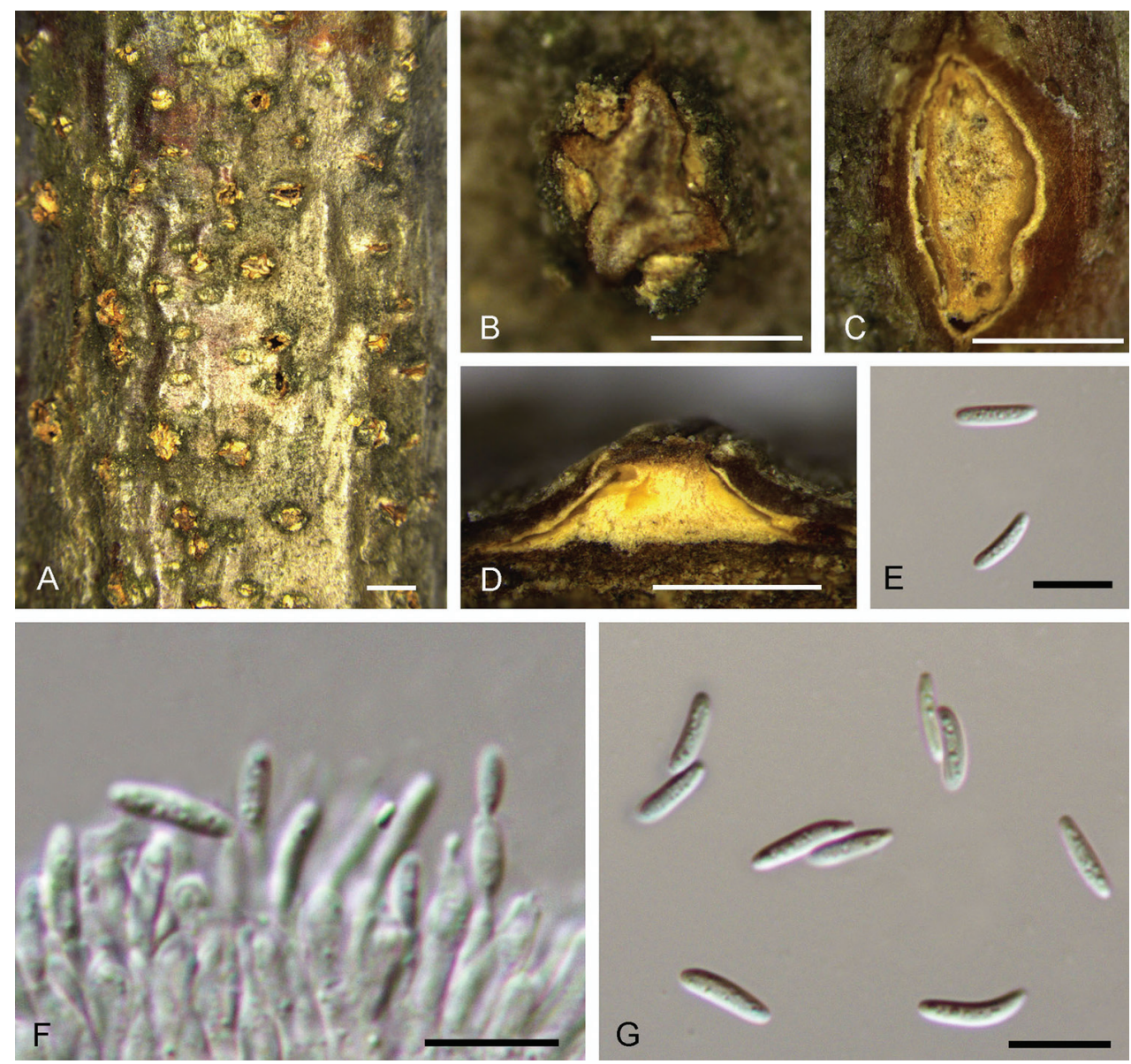

Figure I I. Morphology of Dendrostoma shaanxiense from Castanea mollissima (BJFC-S1549). A, B Habit of conidiomata on branches $\mathbf{C}$ Transverse section of conidioma $\mathbf{D}$ Longitudinal section through conidioma E, G Conidia F Conidiogenous cells. Scale bars: $1 \mathrm{~mm}(\mathbf{A}) ; 0.5 \mathrm{~mm}(\mathbf{B}-\mathbf{D}) ; 10 \mu \mathrm{m}(\mathbf{E}-\mathbf{G})$.

Culture characters. On PDA, cultures are initially white, turning purple after 2 weeks on PDA. The colonies are flat with irregular edge; texture uniform, producing concentric circles within 1 month at $25^{\circ} \mathrm{C}$ in the dark.

Additional specimen examined. Shaanxi Province: Ankang City, Xiangxidong Park, $32^{\circ} 40^{\prime} 32^{\prime \prime} \mathrm{N}, 109^{\circ} 18^{\prime} 57^{\prime \prime E}, 1079 \mathrm{~m}$ a.s.l., on branches of Castanea mollissima, 1 Jul. 2017, N. Jiang, CFCC 52742 (BJFC-S1550).

Notes. Dendrostoma shaanxiense, D. castaneae and D. castaneicola are phylogenetically closely related species occurring on the same host, Castanea mollissima (Fig. 2). However, Dendrostoma shaanxiense has conidia with a smaller $1 /$ w ratio than $D$. castaneae (3.3-4.2 in D. shaanxiense vs. 4.2-5.2 in D. castaneae) and has narrower conidia than D. castaneicola $(2.5-3.1 \mu \mathrm{m}$ diam. in D. shaanxiense vs. 3.2-3.8 $\mu \mathrm{m}$ diam. in D. castaneicola). 


\section{Dendrostoma shandongense C.M. Tian \& N. Jiang, sp. nov.}

MycoBank: MB826826

Figure 12

Diagnosis. Dendrostoma shandongense is distinguished from its closest relative $D$. chinensis by the colour of conidiomata.

Holotype. CHINA. Shandong Province: Rizhao City, Donggang District, chestnut plantation, $35^{\circ} 42^{\prime} 28^{\prime \prime} \mathrm{N}, 119^{\circ} 46^{\prime} 23^{\prime \prime E}, 452 \mathrm{~m}$ a.s.l., on branches of Castanea mollissima, 14 Apr. 2017, N. Jiang (holotype: BJFC-S1567; ex-type culture: CFCC 52759).

Etymology. Shandongense, referring to the Shandong Province in China.

Description. Sexual morph not observed. Asexual morph: Conidiomata pycnidial, spherical, occurring separately, reddish-orange, semi-immersed in bark, $250-400 \mu \mathrm{m}$
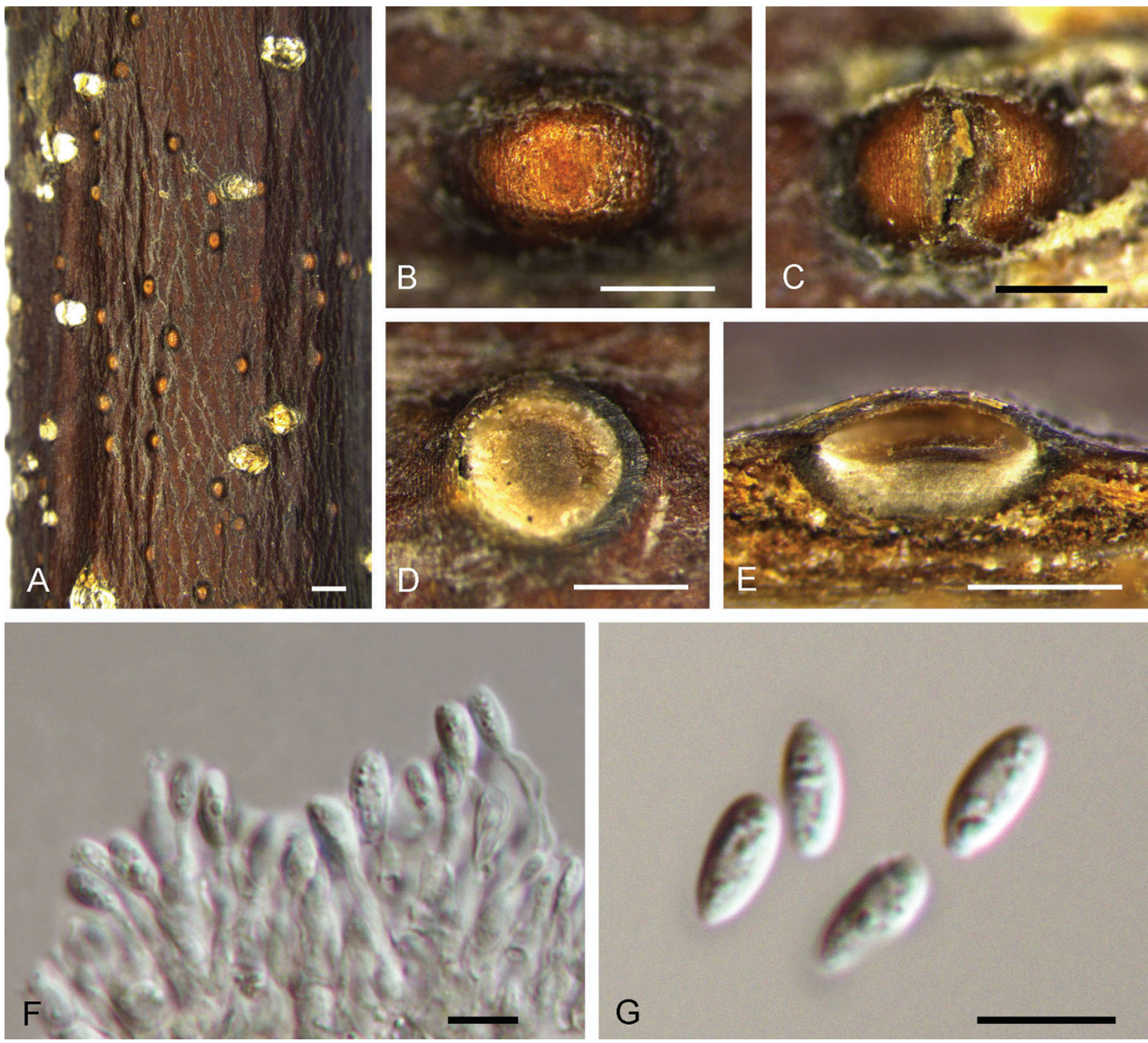

Figure I 2. Morphology of Dendrostoma shandongense from Castanea mollissima (BJFC-S1567). A-C Habit of conidiomata on branches D Transverse section of conidioma $\mathbf{E}$ Longitudinal section through conidioma F Conidiogenous cells $\mathbf{G}$ Conidia. Scale bars: $1 \mathrm{~mm}(\mathbf{A}) ; 0.3 \mathrm{~mm}(\mathbf{B}-\mathbf{D}) ; 5 \mu \mathrm{m}(\mathbf{F}) ; 5 \mu \mathrm{m}(\mathbf{G})$. 
Table 2. Conidial size of Dendrostoma species from natural host barks, species with * were measured from conidia produced in PDA.

\begin{tabular}{lccc}
\hline \multicolumn{1}{c}{ Species } & Conidial length $(\boldsymbol{\mu m})$ & Conidial width $(\boldsymbol{\mu m})$ & Length/width ratio \\
\hline Dendrostoma aurorae & $8.1-9.8$ & $2.3-2.6$ & $3.2-4.1$ \\
Dendrostoma castaneae & $10.4-12.3$ & $2.2-2.7$ & $4.2-5.2$ \\
Dendrostoma castaneicola & $10.5-12.8$ & $3.2-3.8$ & $3-4$ \\
Dendrostoma chinense & $7.7-9.1$ & $3.4-3.7$ & $2.2-2.6$ \\
Dendrostoma dispersum & $11.1-12.2$ & $2-2.3$ & $4.9-5.9$ \\
Dendrostoma mali ${ }^{*}$ & $3.5-4.5$ & $2-2.5$ & $\mathrm{NA}$ \\
Dendrostoma osmanthi & $7.5-10.5$ & $2-2.5$ & $\mathrm{NA}$ \\
Dendrostoma parasiticum & $9.3-11.7$ & $2.8-3.3$ & $3-3.9$ \\
Dendrostoma qinlingense & $16-18$ & $3.3-3.7$ & $4.4-5.2$ \\
Dendrostoma quercinum & & 2.5 & $\mathrm{NA}$ \\
Dendrostoma quercus & $10.5-14$ & $3.5-4.2$ & $3.3-4.4$ \\
Dendrostoma shanxiense & $13.3-16.1$ & $2.5-3.1$ & $3.3-4.2$ \\
Dendrostoma shandongense & $9.5-11.1$ & $3.8-4.3$ & $1.9-2.3$ \\
\hline
\end{tabular}

high, 450-650 $\mu \mathrm{m}$ diam.; wall of several layers of black textura angularis. Conidiophores reduced to conidiogenous cells. Conidiogenous cells lining the inner walls of cavity, hyaline, smooth, ampulliform, 6.5-13 × 1-2.5 $\mu \mathrm{m}$. Conidia hyaline, aseptate, smooth, multiguttulate, thin-walled, fusoid to ellipsoid, apex acutely rounded, base truncate, $(7.8-) 8.1-8.8(-9) \times(3.7-) 3.8-4.3(-4.8) \mu \mathrm{m}, 1 / \mathrm{w}=(1.6-) 1.9-2.3(-2.4)(\mathrm{n}=50)$.

Culture characters. On PDA, cultures are white. The colonies are flat with irregular edge; texture uniform, producing sparse conidiomata irregularly distributed near the centre of the plate within 1 month at $25^{\circ} \mathrm{C}$ in the dark.

Additional specimen examined. Shandong Province: Rizhao City, Donggang District, chestnut plantation, 35 $42^{\prime} 28^{\prime \prime} \mathrm{N}, 119^{\circ} 46^{\prime} 23^{\prime \prime} \mathrm{E}, 452 \mathrm{~m}$ a.s.l., on branches of Castanea mollissima, 14 Apr. 2017, N. Jiang, CFCC 52760 (BJFC-S1568).

Notes. Dendrostoma shandongense and D. chinensis occasionally occur on the same branches. These species are best distinguished by the appearance of their conidiomata, which are black in Dendrostoma chinense and orange in D. shandongense.

\section{Discussion}

In this study, we reviewed the taxonomic circumscription of Dendrostoma using molecular and morphological data. This is the first study that presents a robust phylogeny using a number of Dendrostoma isolates from different geographic origins. The results revealed up to 14 species in Dendrostoma based on the observation of type specimens and ex-type cultures (D. leiphaemia was not observed), of which 10 species were shown to represent new species, namely $D$. aurorae, $D$. castaneae, $D$. castaneicola, $D$. chinense, $D$. dispersum, $D$. parasiticum, D. qinlingense, $D$. quercus, $D$. shaanxiense and $D$. shandongense.

The 13 type specimens in Dendrostoma (except D. leiphaemia) were examined to establish robust morphological characteristics amongst specific ranks. Amongst these, 3 species, Dendrostoma mali, D. osmanthi and D. quercinum, were discovered 


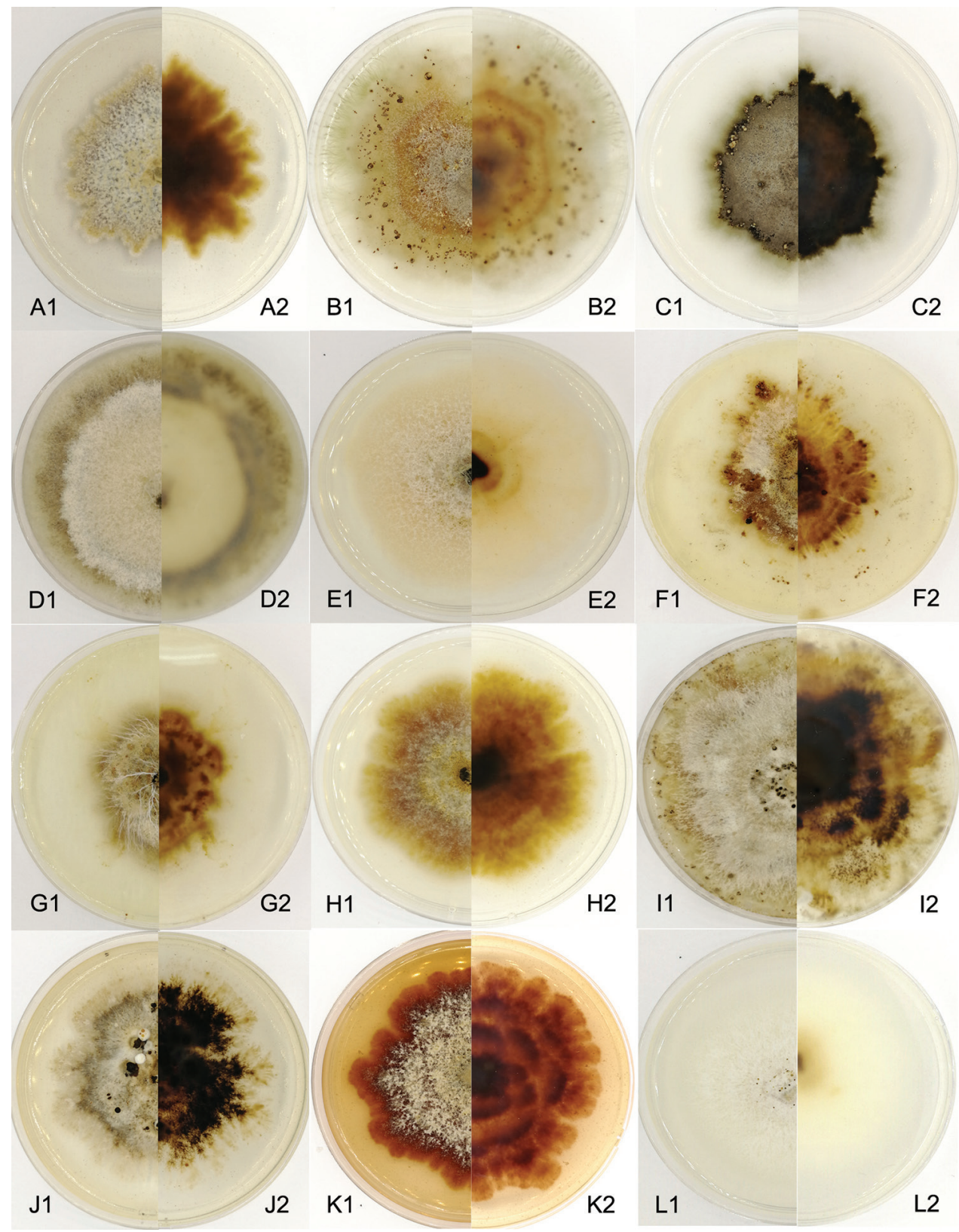

Figure 13. Dendrostoma cultures on PDA after 1 month at $25^{\circ} \mathrm{C}, \mathbf{A} D$. aurorae $\mathbf{B} D$. castaneae $\mathbf{C} D$. castaneicola $\mathbf{D} D$. chinense $\mathbf{E} D$. dispersum $\mathbf{F}-\mathbf{G} D$. osmanthi $\mathbf{H} D$. parasiticum $\mathbf{I} D$. qinlingense $\mathbf{J} D$. quercus; $\mathbf{K} D$. shaanxiense $\mathbf{L} D$. shandongense.

to only have a sexual morph on natural hosts; 9 species, D. aurorae, D. castaneae, $D$. castaneicola, $D$. chinense, $D$. dispersum, $D$. parasiticum, $D$. qinlingense, $D$. shaanxiense and $D$. shandongense, were observed with only an asexual morph and only one species, $D$. quercus, was represented by both asexual and sexual morphs. Hence, 
morphological differences amongst Dendrostoma species were mainly established based on conidiomata produced on diseased host tissues, including colours of conidiomata, culture characteristics (Fig. 13), existence or non-existence of a central column, conidial shape and dimensions.

Dendrostoma shandongense and D. chinense are similar in conidial shape and size, but differ markedly from the other species. Additionally, Dendrostoma shandongense and $D$. chinense comprise the only two species in the genus with conidiomata lacking a central column structure, although they differ considerably with regard to in conidiomatal appearance (Figs. 6, 13). The remaining eight species differ by the existence of a central column inside the conidiomata and can be further distinguished by their conidial characteristics, namely length, width and 1/w ratio. Additionally, a key to the 14 Dendrostoma species is provided below.

\section{Key to Dentrostoma species}

1 Asexual morphs with or without sexual morphs known from natural sub-

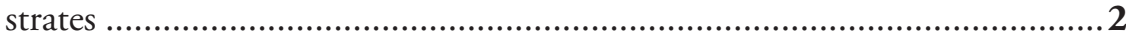

- Only sexual morph known from natural substrates ..............................11

2 Central column absent, length/width ratio of conidia $<3 \ldots \ldots \ldots \ldots \ldots \ldots \ldots . . . . . . .3$

- Central column present, length/width ratio of conidia $>3 \ldots \ldots \ldots \ldots \ldots \ldots \ldots . . . .4$

3 Conidiomata orange ............................................ D. shandongense

- Conidiomata black ............................................................ D. chinense

4 Conidia dimorphic ........................................................... quercus

- Conidia monomorphic .................................................................... 5

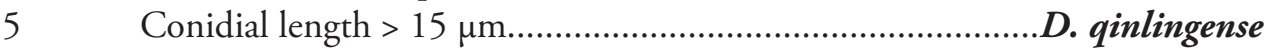

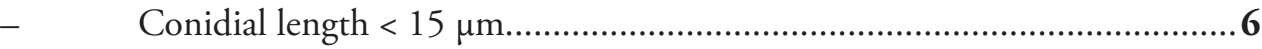

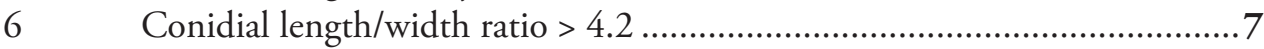

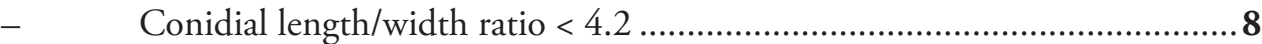

7 Conidial length/width ratio 4.2-5.2, conidial width 2.2-2.7 $\mu \mathrm{m}$... D. castaneae

- $\quad$ Conidial length/width ratio 4.9-5.9, conidial width 2-2.3 $\mu$ m...D. dispersum

8 Central column white

D. castaneicola

Central column bright yellow or pale yellow .........................................9

9 Central column pale yellow ................................................ D. aurorae

- Central column bright yellow ........................................................... 10

10 Conidial width $2.8-3.3 \mu \mathrm{m}$, length/width ratio 3-3.9 ....... D. parasiticum Conidial width $2.5-3.1 \mu \mathrm{m}$, length/width ratio 3.3-4.2 ......D. shaanxiense

11 Ascospores width $>5 \mu \mathrm{m}$............................................ D. leiphaemia

Ascospores width $<5 \mu \mathrm{m}$............................................................. 12

12 Ascospores length $>15 \mu \mathrm{m}$............................................ D. quercinum

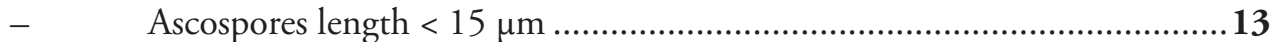

13 On Osmanthus, Ascospores 11.5-14.5 × 3.5-4 $\mu \mathrm{m}$................. D. osmanthi

On Malus, Ascospores 12-14 × 3-4 $\mu \mathrm{m}$................................... D. mali 
The genus Dendrostoma was initially proposed to include three presumed plant pathogens causing canker diseases on hardwood trees, namely D. mali on Malus spectabilis, D. osmanthi on Osmanthus fragrans and D. quercinum on Quercus acutissima (Fan et al. 2018). Consistent with the previous study, the newly described 10 species were all isolated from fruiting structures associated with typical canker symptoms on several hardwood tree species, namely Castanea mollissima and Quercus spp.

The tree genera Castanea and Quercus in Fagaceae contain numerous important and common tree species in China, including C. mollissima, C. crenata, C. henryi, $C$. seguinii, Q. acutissima, Q. aliena, Q. dentata, Q. mongolica and Q. wutaishanica (Flora of China website: http://frps.eflora.cn/). Castanea mollissima constitutes one the most important crop tree species widely cultivated in 26 provinces in China. However, many plantations and nurseries planting Chinese chestnut suffer from fungal diseases that cause high production losses (Jiang et al. 2018). In particular, chestnut blight caused by Cryphonectria parasitica represents the most serious fungal disease, reducing host vitality and potentially killing the host (Jiang et al. 2018, Rigling and Prospero 2018).

In the present study, seven Dendrostoma species were observed on the host Castanea mollissima including $D$. aurorae, $D$. castaneae, D. castaneicola, D. chinense, D. parasiticum, $D$. shaanxiense and $D$. shandongense, causing chestnut canker diseases, termed Dendrostoma canker herein. Dendrostoma canker constitutes a newly discovered disease that has been observed in chestnut plantations and nurseries. Species of Dendrostoma usually infect host branches and stems, with occasional infection of twigs. Maturation of the fruiting structures from June to July resulted in death of the infected branches. Notably, no sexual fruiting structures were discovered during our investigations on chestnut trees.

Accurate recognition and identification of plant diseases are essential as fungal pathogens are constantly evolving and traditional control methods are frequently insufficient for disease control. In comparison, in the present study, Dendrostoma canker is considered to be caused by up to eight different species of Dendrostoma. Further studies are, however, required to confirm their pathogenicity and fully resolve their ecology.

\section{Acknowledgements}

This study was financed by the National Natural Science Foundation of China (Project No.: 31670647). We thank Yingmei Liang [Museum of Beijing Forestry University (BJFC), Beijing Forestry University], Chungen Piao and Minwei Guo [China Forestry Culture Collection Center (CFCC), Chinese Academy of Forestry, Beijing] for the preservation of materials studied during this study.

\section{References}

Carbone I, Kohn LM (1999) A method for designing primer sets for speciation studies in filamentous ascomycetes. Mycologia 91: 553-556. https://doi.org/10.2307/3761358 
Crous PW, Gams W, Stalpers JA, Robert V, Stegehuis G (2004) MycoBank: an online initiative to launch Mycology into the $21^{\text {st }}$ century. Studies in Mycology 50: 19-22.

Crous PW, Summerell BA, Alfenas AC, Edwards J, Pascoe IG, Porter IJ, Groenewald JZ (2012a)

Genera of diaporthalean coelomycetes associated with leaf spots of tree hosts. Persoonia 28: 66-75. https://doi.org/10.3767/003158512X642030

Crous PW, Summerell BA, Shivas RG, Burgess TI, Decock CA, Dreyer LL, Granke LL, Guest DI, Hardy GE, Hausbeck MK, Hüberli D, Jung T, Koukol O, Lennox CL, Liew ECY, Lombard L, McTaggart AR, Pryke JS, Roets F, Saude C, Shuttleworth LA, Stukely MJC, Vánky K, Webster BJ, Windstam ST, Groenewald JZ (2012b) Fungal Planet description sheets: 107-127. Persoonia 28: 138-182. https://doi.org/10.3767/003158512X652633

Crous PW, Wingfield MJ, Burgess TI, Hardy GSJ, Barber PA, Alvarado P, Barnes CW, Buchanan PK, Heykoop M, Moreno G, Thangavel R, van der Spuy S, Barili A, Barrett S, Cacciola SO, Cano-Lira JF, Crane C, Decock C, Gibertoni TB, Guarro J, Guevara-Suarez M, Hubka V, Kolařík M, Lira CRS, Ordońez ME, Padamsee M, Ryvarden L, Soares AM, Stchigel AM, Sutton DA, Vizzini A, Weir BS, Acharya K, Aloi F, Baseia IG, Blanchette RA, Bordallo JJ, Bratek Z, Butler T, Cano-Canals J, Carlavilla JR, Chander J, Cheewangkoon R, Cruz RHSF, da Silva M, Dutta AK, Ercole E, Escobio V, Esteve-Raventós F, Flores JA, Gené J, Góis JS, Haines L, Held BW, Jung MH, Hosaka K, Jung T, Jurjević Ž, Kautman V, Kautmanova I, Kiyashko AA, Kozanek M, Kubátová A, Lafourcade M, Spada FL, Latha KPD, Madrid H, Malysheva EF, Manimohan P, Manjón JL, Martín MP, Mata M, Merényi Z, Morte A, Nagy I, Normand AC, Paloi S, Pattison N, Pawłowska J, Pereira OL, Petterson ME, Picillo B, Raj KNA, Roberts A, Rodríguez A, Rodríguez-Campo FJ, Romański M, Ruszkiewicz-Michalska M, Scanu B, Schena L, Semelbauer M, Sharma R, Shouche YS, Silva V, Staniaszek-Kik M, Stielow JB, Tapia C, Taylor PWJ, Toome-Heller M, Vabeikhokhei JMC, Van Diepeningen AD, Van Hoa N, Van Tri M, Wiederhold NP, Wrzosek M, Zothanzama J, Groenewald JZ (2017) Fungal Planet description sheets: 558-624. Persoonia 38: 240-384. https://doi.org/10.3767/003158517X698941

Crous PW, Wingfield MJ, Burgess TI, Hardy GSJ, Crane C, Barrett S, Cano-Lira JF, Le Roux JJ, Thangavel R, Guarro J, Stchigel AM, Martín MP, Alfredo DS, Barber PA, Barreto RW, Baseia IG, Cano-Canals J, Cheewangkoon R, Ferreira RJ, Gené J, Lechat C, Moreno G, Roets F, Shivas RG, Sousa JO, Tan YP, Wiederhold NP, Abell SE, Accioly T, Albizu JL, Alves JL, Antoniolli ZI, Aplin N, Araújo J, Arzanlou M, Bezerra JDP, Bouchara JP, Carlavilla JR, Castillo A, Castroagudín VL, Ceresini PC, Claridge GF, Coelho G, Coimbra VRM, Costa LA, da Cunha KC, da Silva SS, Daniel R, de Beer ZW, Dueñas M, Edwards J, Enwistle P, Fiuza PO, Fournier J, García D, Gibertoni TB, Giraud S, Guevara-Suarez M, Gusmão LFP, Haituk S, Heykoop M, Hirooka Y, Hofmann TA, Houbraken J, Hughes DP, Kautmanová I, Koppel O, Koukol O, Larsson E, Latha KPD, Lee DH, Lisboa DO, Lisboa WS, López-Villalba Á, Maciel JLN, Manimohan P, Manjón JL, Marincowitz S, Marney TS, Meijer M, Miller AN, Olariaga I, Paiva LM, Piepenbring M, Poveda-Molero JC, Raj KNA, Raja HA, Rougeron A, Salcedo I, Samadi R, Santos TAB, Scarlett K, Seifert KA, Shuttleworth LA, Silva GA, Silva M, Siqueira JPZ, Souza-Motta CM, Stephenson SL, Sutton DA, Tamakeaw N, Telleria MT, Valenzuela-Lopez N, Viljoen A, Visagie 
CM, Vizzini A, Wartchow F, Wingfield BD, Yurchenko E, Zamora JC, Groenewald JZ (2016). Fungal Planet description sheets: 469-557. Persoonia 37: 218-403. https://doi. org/10.3767/003158516X694499

Doyle JJ, Doyle JL (1990) Isolation of plant DNA from fresh tissue. Focus 12: 13-15.

Fan XL, Bezerra JD, Tian CM, Crous PW (2018) Families and genera of diaporthalean fungi associated with canker and dieback of tree hosts. Persoonia 40: 119-134. https://doi. org/10.3767/persoonia.2018.40.05

Ferreira FA, Demuner NL, Rezende DV (1992) Mancha de folha, des folha e antracnose do Jatobá (Hymenaea spp.) causadas por Erythrogloeum hymenaeae. Fitopatologia Brasileira 17: 106-109.

Guindon S, Dufayard JF, Lefort V, Anisimova M, Hordijk W, Gascuel O (2010) New algorithms and methods to estimate maximum-likelihood phylogenies: assessing the performance of PhyML 3.0. Systematic Biology 59: 307-321. https://doi.org/10.1093/sysbio/syq010

Hillis DM, Bull JJ (1993) An empirical test of bootstrapping as a method for assessing confidence in phylogenetic analysis. Systematic Biology 42: 182-192. https://doi.org/10.1093/ sysbio/42.2.182

Jiang N, Fan X, Yang Q, Du Z, Tian CM (2018) Two novel species of Cryphonectria from Quercus in China. Phytotaxa 347: 243-250. https://doi.org/10.11646/phytotaxa.347.3.5

Katoh K, Toh H (2010) Parallelization of the MAFFT multiple sequence alignment program. Bioinformatics 26: 1899-1900. https://doi.org/10.1093/bioinformatics/btq224

Liu YJ, Whelen S, Hall BD (1999) Phylogenetic relationships among ascomycetes: evidence from an RNA polymerse II subunit. Molecular Biology and Evolution 16: 1799-1808. https://doi.org/10.1093/bioinformatics/btq224

Petrak F (1953) Erythrogloeum n. gen., eine neue Gattung der Sphaeropsideen. Sydowia 7: 378-380.

Rigling D, Prospero S (2018) Cryphonectria parasitica, the causal agent of chestnut blight: Invasion history, population biology and disease control. Molecular Plant Pathology 19: 7-20. https://doi.org/10.1111/mpp.12542

Rossman AY, Farr DF, Castlebury LA (2007) A review of the phylogeny and biology of the Diaporthales. Mycoscience 48: 135-144. https://doi.org/10.1007/S10267-007-0347-7

Senanayake IC, Crous PW, Groenewald JZ, Maharachchikumbura SS, Jeewon R, Phillips AJL, Bhat JD, Perera RH, Li QR, Li WJ, Tangthirasunun N, Norphanphoun C, Karunarathna SC, Camporesi E, Manawasighe IS, Al-Sadi AM, Hyde KD (2017) Families of Diaporthales based on morphological and phylogenetic evidence. Studies in Mycology 86: 217-296. https://doi.org/10.1016/j.simyco.2017.07.003

Senanayake IC, Jeewon R, Chomnunti P, Wanasinghe DN, Norphanphoun C, Karunarathna A, Pem D, Perera RH, Camporesi E, McKenzie EHC, Hyde KD, Karunarathna SC (2018) Taxonomic circumscription of Diaporthales based on multigene phylogeny and morphology. Fungal Diversity 93: 241-443. https://doi.org/10.1007/s13225-018-0410-z

Tamura K, Stecher G, Peterson D, Filipski A, Kumar S (2013) MEGA6: Molecular Evolutionary Genetics Analysis version 6.0. Molecular Biology and Evolution 30: 2725-2729. https://doi.org/10.1093/molbev/mst197 
Vilgalys R, Hester M (1990) Rapid genetic identification and mapping of enzymatically amplified ribosomal DNA from several Cryptococcus species. Journal of Bacteriology 172: 42384246. https://doi.org/10.1128/jb.172.8.4238-4246.1990

Voglmayr H, Castlebury LA, Jaklitsch WM (2017) Juglanconis gen. nov. on Juglandaceae, and the new family Juglanconidaceae (Diaporthales). Persoonia 38: 136-155. https://doi. org/10.3767/003158517X694768

Voglmayr H, Jaklitsch WM (2014) Stilbosporaceae resurrected: generic reclassification and speciation. Persoonia 33: 61-82. https://doi.org/10.3767/003158514X684212

White TJ, Bruns T, Lee S, Taylor JL (1990) Amplification and direct sequencing of fungal ribosomal RNA genes for phylogenetics. PCR Protocols: a guide to methods and applications 18: 315-322. https://doi.org/10.1016/B978-0-12-372180-8.50042-1

Zhang YJ, Zhang S, Liu XZ, Wen HA, Wang M (2010) A simple method of genomic DNA extraction suitable for analysis of bulk fungal strains. Letters in applied microbiology 51: 114-118. https://doi.org/10.1111/j.1472-765X.2010.02867.x 